\title{
Pleistocene raised marine terraces of the Spanish Mediterranean and Atlantic coasts: records of coastal uplift, sea-level highstands and climate changes
}

\author{
Cari Zazo ${ }^{\mathrm{a}, *}$, José Luis Goy ${ }^{\mathrm{b}}$, Cristino J. Dabrio ${ }^{\mathrm{c}}$, Teresa Bardají ${ }^{\mathrm{d}}$, \\ Claude Hillaire-Marcel ${ }^{\mathrm{e}}$, Bassam Ghaleb ${ }^{\mathrm{e}}$, José-Ángel González-Delgado ${ }^{\mathrm{b}}$, \\ Vicente Soler ${ }^{\mathrm{f}}$ \\ a Departamento de Geología, Museo Nacional de Ciencias Naturales-CSIC, 28006 Madrid, Spain \\ b Departamento de Geología, Facultad de Ciencias, Universidad, 37008 Salamanca, Spain \\ c Departamento de Estratigrafia-UCM and Instituto de Geología Económica-CSIC, Universidad Complutense, 28040 Madrid, Spain \\ d Departamento de Geología, Facultad de Ciencias, Universidad, 28871 Alcalá de Henares, Madrid, Spain \\ e Université du Québec à Montréal, GEOTOP-UQAM, Montreal, QC, Canada H3C 3P8 \\ ${ }^{\mathrm{f}}$ Estación Volcanológica de Canarias, Instituto de Productos Naturales-CSIC, Avenida Astrofisico Francisco Sánchez 3, \\ 38206 La Laguna, Tenerife, Spain
}

Received 15 March 2001; accepted 21 October 2002

\begin{abstract}
Detailed geological mapping, morphostratigraphic, palaeontological and geochronological (uranium-series) analyses were undertaken on the raised marine terraces and interbedded terrestrial deposits along the Spanish peninsular and insular Atlantic and Mediterranean coasts. Several sets of Pleistocene shallow-marine to coastal deposits exposed in a staircase arrangement are interpreted as being emplaced during sea-level highstands coeval with interglacials or interstadials correlating with marine Oxygen Isotopic Stages (OIS) 5a/5c, 5e, 7, 9/11 and older. Up to three highstands have been identified in deposits formed during OIS 5e. Close to the end of OIS 5e there is a record of sudden changes in sea-surface conditions and climate marked by the disappearance of a major proportion of the warm 'Senegalese' fauna, switches from oolitic to non-oolitic facies, and accumulation of boulder beaches. Dating of the coral Cladocora caespitosa, found in a layer that also contains Strombus bubonius, confirms the occurrence of warm fauna in the Mediterranean basin during OIS 7, as previously suggested by Hillaire-Marcel et al. (1986), Goy et al. (1986a,b), Zazo and Goy (1989). Also the occurrence of warm faunas in deposits corresponding to an older interglacial, probably OIS 9 or 11, in the Balearic Islands suggests similar oceanographic conditions (sea-surface temperature, assuming constant salinity) during the last interglacial and at least two interglacials of the Middle Pleistocene in the western Mediterranean.
\end{abstract}

Keywords: interglacial; marine oxygen isotopic stages; Iberian Peninsula; Canary Islands; Balearic Islands 


\section{Introduction}

Several sets of staircased Quaternary marine deposits occur along the Spanish littoral between ca. $100 \mathrm{~m}$ above mean sea level (asl) and present sea level. Previous studies have dealt with the geological and geomorphic features, sedimentary, palaeontological and geochronological interpretations of these deposits on the Atlantic coasts including the Canary Islands (Zazo et al., 1997, 1999), and the Mediterranean coasts including the Balearic Islands (Butzer and Cuerda, 1962; Butzer, 1975; Cuerda, 1989; Goy and Zazo, 1982; Goy et al., 1986a,b, 1993a,b; Somoza, 1993; Bardají et al., 1999).

U-series measurements have been carried out in the pre-Holocene marine terraces particularly in the Mediterranean area (Stearns and Thurber, 1965, 1967; Bernat et al., 1978, 1982; HillaireMarcel et al., 1986, 1996; Causse et al., 1993; McLaren and Rowe, 1996); in contrast, radiometric data are scarce in the Atlantic littoral (Radtke, 1985; Meco et al., 1992; Zazo et al., 1997, 1999).

In addition to isotopic dating, amino acid racemisation (AAR) analysis of the fossil fauna collected from raised marine deposits has been undertaken (Hearty, 1986, 1987; Hearty et al., 1986, 1987). Five 'aminozones' (C, E, F, G, and $\mathrm{K})$ assumed to represent separate transgressiveregressive cycles of increasing age were subsequently established in the Mediterranean basin. Aminozone $\mathrm{C}$ is thought to represent a late Stage 5 event. Aminozone $\mathrm{E}$ has been correlated with marine Oxygen Isotopic Stage (OIS) 5e of the marine record based upon eight U-series data obtained from the fossil coral Cladocora caespitosa found in six sites, two of which are located on the coasts of Spain at Cape Huertas (Alicante) and Son Grauet (Mallorca). Aminozones F, G, and $\mathrm{K}$ are currently related to earlier periods.

In spite of the relatively rich literature, the correlation of raised marine terraces found in the various coastal areas is still problematic due to variable tectonic behaviours and the scarcity of coral remains, which limits U-series measurements to mollusc shells with the associated risks involved (Kaufman et al., 1971).

Since the work of Shackleton and Opdyke
(1973, 1976) on deep-sea cores V28-238 and V28-239, the chronostratigraphy of the Pleistocene has been closely linked to marine oxygen isotope stratigraphy. However, the correlation between marine OIS and emerged marine terraces is still largely problematic mainly because of the limitations of geochronological methods. Nevertheless, we consider that the study of raised marine terraces that formed contemporary with sealevel highstands in areas subjected to uplift offers the potential to provide new information about Pleistocene uplift and some climatic records and deserves investigation.

A common feature of recent Pleistocene deposits on the Mediterranean coasts of Spain is the occurrence of a warm 'Senegalese' fauna (Strombus bubonius/Strombus latus, Brachidontes senegalensis, Hyotissa hyotis, Cantharus viverratus, Conus testudinarius, Cymatium dolarium, etc.) of equatorial African origin, which entered the Mediterranean through the Gibraltar Strait in the middlelate Pleistocene as pointed out by Gignoux (1913) and Issel (1914). These authors considered $S$. bubonius a guide fossil in the Mediterranean, still living on the tropical coasts of Africa. There is major discussion about the number of marine terraces containing $S$. bubonius in our study area. Some researchers maintain that $S$. bubonius is exclusively associated with OIS 5e (McLaren and Rowe, 1996) or 'aminozone E' (Hearty, 1986, 1987; Hearty et al., 1986, 1987) whereas others (Hillaire-Marcel et al., 1986; Goy et al., 1986b; Zazo and Goy, 1989) consider that it first entered the Mediterranean during OIS 7, came massively in OIS 5e, and survived in some privileged sites (Almería) during the whole interglacial.

The aim of this paper is to describe and analyse the records of Pleistocene coastal uplift, sea-level and, concisely, climate changes provided by raised marine terraces in the Western Mediterranean and northeastern Atlantic. The study is based upon geologic and geomorphic mapping and morphostratigraphic, palaeontological and geochronological analyses of terraces and terrace deposits. We have earlier studied some of these areas (Almería, Murcia, Alicante, and partly Balearic and Canary Islands), but we present new data including U-series measurements by thermal ionisation 
mass spectrometry (TIMS) on mollusc shells, which allow us to revise and re-interpret many of the earlier findings.

\section{Methods}

Geological mapping was based on field observations and stereoscopic study of three sets of aerial photographs scaled at 1: 32000 (1957, Servicio Geográfico del Ejército) covering all the surveyed areas, 1: 15000 (1960, Instituto Geográfico Nacional) used in Almería, and 1: 5000 (1989-90, Ministerio de Obras Públicas y Urbanismo-MOPU, Vuelo de Costas) used for Almería and Canary Islands.

We undertook detailed facies analysis of deposits associated with the marine terraces, to determine the influence of eustatic changes in sea level on the formation of individual terraces and to permit the correlation of terraces between study sites. In particular, we investigated deposits that contain a plunge-step facies indicative of the lower foreshore that provide excellent indicators of local sea level in the microtidal setting of the Mediterranean. The elevations that we report refer to the elevation above mean sea level (asl) of the inner edge of the terraces. The mean annual high tide was used as datum in the mesotidal Canary Islands.

Palaeontological studies included the taphonomy (fragmentation, abrasion, bioerosion, and encrustation) and palaeoecology of macrofauna. Palaeomagnetic analyses have previously been carried out on several outcrops of coastal sediments at Almería, Murcia and Alicante (Goy et al., 1989), but in this paper we consider only the data from Cope Basin (Murcia).

All stratigraphic sections discussed in this paper have previously been sampled for U-series dating by TIMS and $\alpha$-spectrometry (Hillaire-Marcel et al., 1986, 1996; Causse et al., 1993). In this paper we complement these data with new U-series measurements by TIMS for deposits on the Canary Islands, Alicante province and Balearic Islands. Corals are very rarely found in the study area: the only previously known occurrences in Spain were some sites on the southern coast of Mallorca
Island (Hearty et al., 1986; Cuerda, 1989) and Cape Huertas in Peninsular Spain (Hearty, 1986), to which we add a new site (La Marina, Alicante province). Given the almost complete $a b-$ sence of corals in the study area, we have dated mollusc shells. Seriate measurements of $U$ isotopes in modern and fossil mollusc shells have shown that most of the uranium present in these shells is of diagenetic origin (Kaufman et al., 1996; Labonne and Hillaire-Marcel, 2000). However, U-series ages from such fossils may provide good estimates for the true age of the embedding sediments under favourable conditions including: (1) fast cementation of littoral deposits such as beach rocks (Hillaire-Marcel et al., 1996), and (2) arid post-depositional conditions with negligible dissolved $\mathrm{U}$ circulation through the deposits (Ortlieb et al., 1992) and low redox conditions with reduced $U$ fluxes in sediment pore water (Fontes et al., 1996). In the present case, the aridity of the studied areas and the strong cementation of most marine terraces seem to fulfil two of these conditions, therefore suggesting that U-series measurements on fossil molluscs should provide a suitable approach for the dating of the most recent marine units.

As the areas investigated acted as tectonically active during the Quaternary, we have calculated uplift rates of the coastal sectors for the last 130 kyr. Calculations were based on the topographic elevations reached by the deposits of OIS 5e that are accurately dated, more laterally continuous and easily correlated using facies similarities and, above all, the faunal content of all of them. OIS 5e has been dated in the study area between 135 and $117 \mathrm{ka}$ (Hillaire-Marcel et al., 1996). Unfortunately, no areas considered tectonically stable have been cited close to our study area where palaeo-sea levels during OIS 5e could be measured. Therefore we are forced to refer the sea level during OIS 5e to the elevations measured in areas considered tectonically stable but located far away. The elevation is $2 \mathrm{~m}$ asl in southern Australia (Murray-Wallace and Belpeiro, 1991) and a similar value in the Bahamas for most of OIS 5e (Neumann and Hearty, 1996) although a rapid excursion before the close of the substage could bring the sea level up to $6 \mathrm{~m}$ asl. 


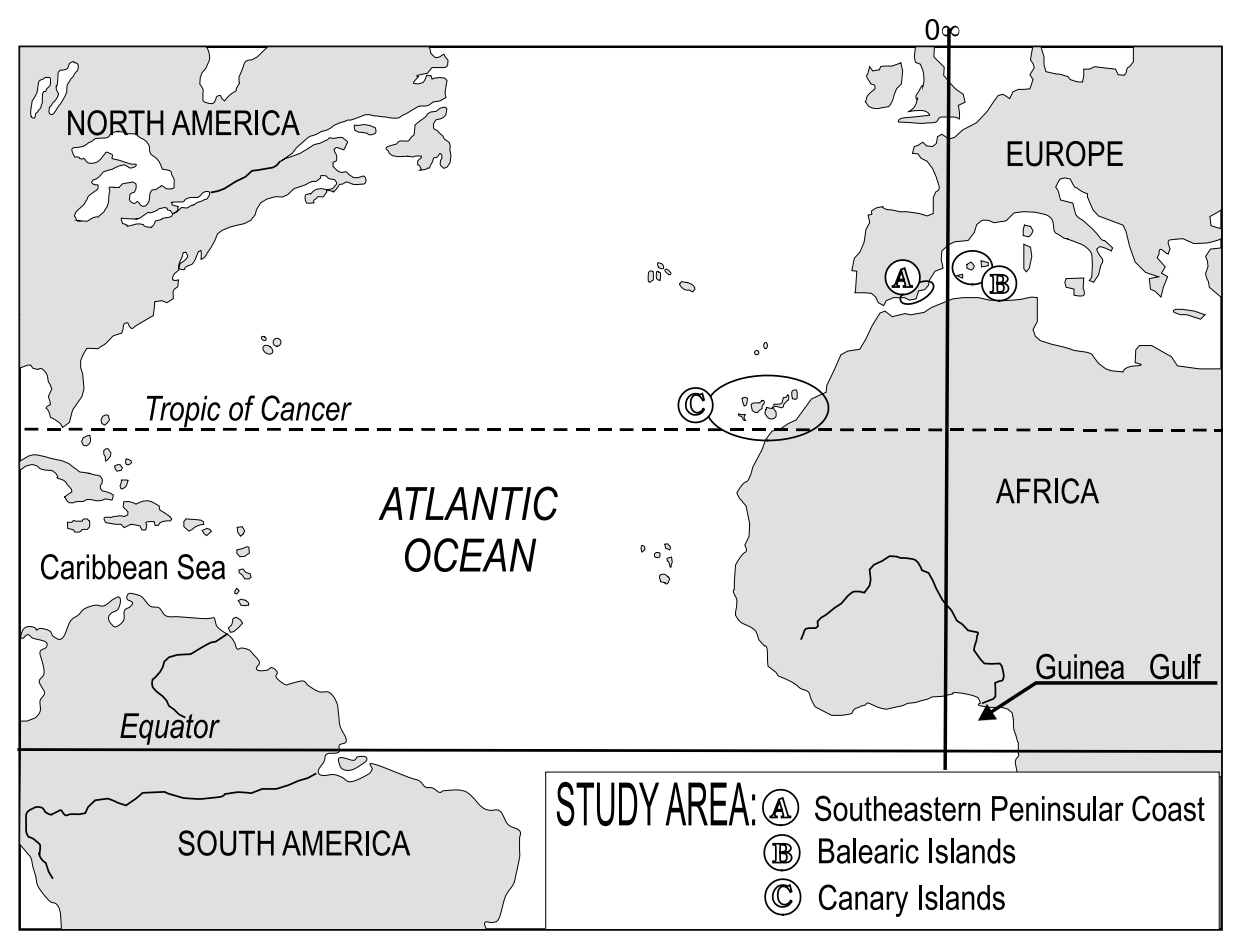

Fig. 1. Location map of the studied areas.

Besides the $+2 \mathrm{~m}$ datum, we assume a constant tectonic movement at least in the last $130 \mathrm{kyr}$.

\section{Geodynamic setting}

The studied sequences occur in areas with very diverse geodynamic and oceanographic settings (Fig. 1). The southeastern Iberian Peninsula and Balearic Islands are located in the microtidal western Mediterranean (tidal range $<0.5 \mathrm{~m}$ ), whereas the Canary Islands lie in the mesotidal Atlantic Ocean (mean annual tidal range $\sim 3 \mathrm{~m}$ ). The tectonic history of both areas is also quite different. The main Quaternary basins in the southeastern Iberian Peninsula (1, 2, 3, Fig. 2) occur along the so-called Eastern Betics left-lateral shear zone (Fig. 2; Montenat et al., 1987), a transcurrent zone developed in response to a continuous northward tectonic indentation of the Águilas Arc from Tortonian until Quaternary times (Coppier et al., 1989), generated by submeridian convergence of the Eurasian and African plates. The morphological expression of this crus- tal structure is the sigmoidal-shaped 'Eastern Betics corridor' (Silva et al., 1993), which separates the Águilas Arc from the rest of the Internal Zones of the Betics. The corridor comprises three morphostructural domains characterised by different tectonic regimes: the Central Segment under wrench tectonics, the transtensional Northern Terminal Splay, and the transpressional Southern Terminal Splay.

The Balearic Islands (Fig. 1) represent the eastern extension of the Betic Cordillera, some 170 $\mathrm{km}$ to the east of the Peninsular coast. The area has been subjected to an extensional tectonic regime since the Late Miocene. Reactivation of tectonic structures directed NE-SW and NW-SE control both the architecture and topographic elevation of Quaternary marine terraces.

The volcanic islands of the Canary archipelago (Fig. 1) are located on a slow-moving oceanic plate close to the African passive continental margin. Volcanism in Lanzarote, Fuerteventura, Gran Canaria and La Gomera islands is old ( $\geq 12 \mathrm{Ma}$ ), subaerial and discontinuous in time. In contrast, volcanism in Tenerife, La Palma and Hierro is- 


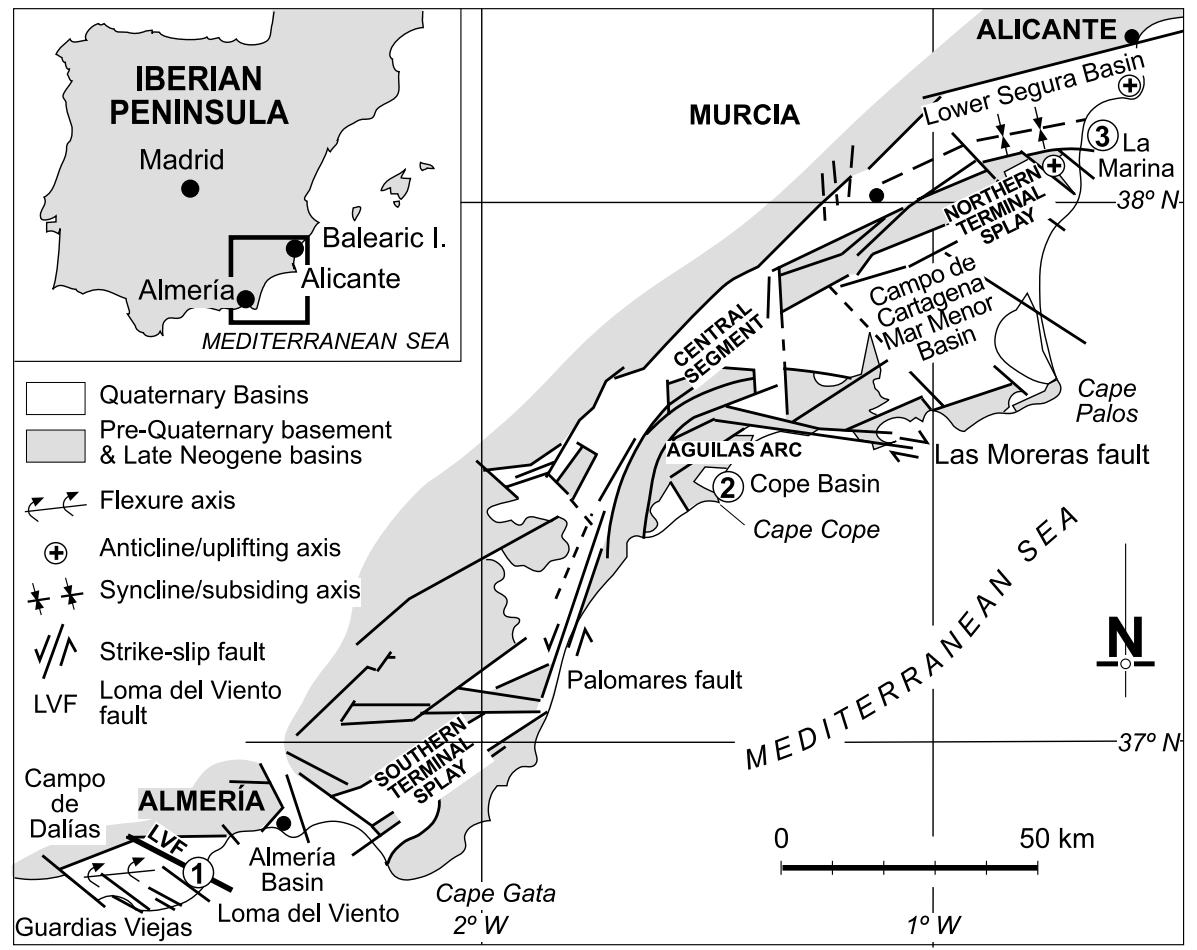

Fig. 2. Tectonic domains of the 'Eastern Betics transcurrent shear zone' (simplified from Silva et al., 1993). 1, 2, 3: Location of studied sites.

lands is younger $(\leq 7.5 \mathrm{Ma})$ and was essentially uninterrupted (Carracedo et al., 1998).

\section{Campo de Dalías}

\subsection{Setting}

This site is located on the western side of the Bay of Almería, in the Southern Terminal Splay of the Eastern Betics left-lateral shear zone (1 in Fig. 2). Faults directed $\mathrm{N} 120^{\circ} \mathrm{E}$ and $\mathrm{N} 10-20^{\circ} \mathrm{E}$ affect both the marine and terrestrial features (Fig. 3). Although faults in the first system are usually normal, some of them have a certain left-lateral component; this is the case of Loma del Viento fault (LVF in Fig. 3). A large part of the area was affected by flexion along two E-W axes since the Early Pleistocene, causing tilting to the north of the Campo de Dalías that became an endorheic basin where the distal deposits of all the alluvial fans draining the Gádor range formed a
E-W elongated facies belt (Fig. 3). The absence of significant alluvial sources barred the generation of the typical alternating marine-terrestrial successions found in many localities described in this paper. Instead, several raised marine terraces occur in unconformity upon the yellow MiddleLate Pliocene calcarenites forming a staircase of terraces. Several papers have presented detailed geological maps, descriptions of lithofacies, sedimentological interpretations, and faunal assemblages of the marine and terrestrial units (Goy and Zazo, 1982; Dabrio et al., 1985; Goy et al., 1986b), U-series measurements of some of the marine units (Hillaire-Marcel et al., 1986; McLaren and Rowe, 1996), AAR analysis (Hearty et al., 1987), and radiocarbon dating (Goy et al., 1986a) in the area.

\subsection{Loma del Viento sector}

The upthrown block of the Loma del Viento fault (Fig. 4) forms an ideal coast for the study 


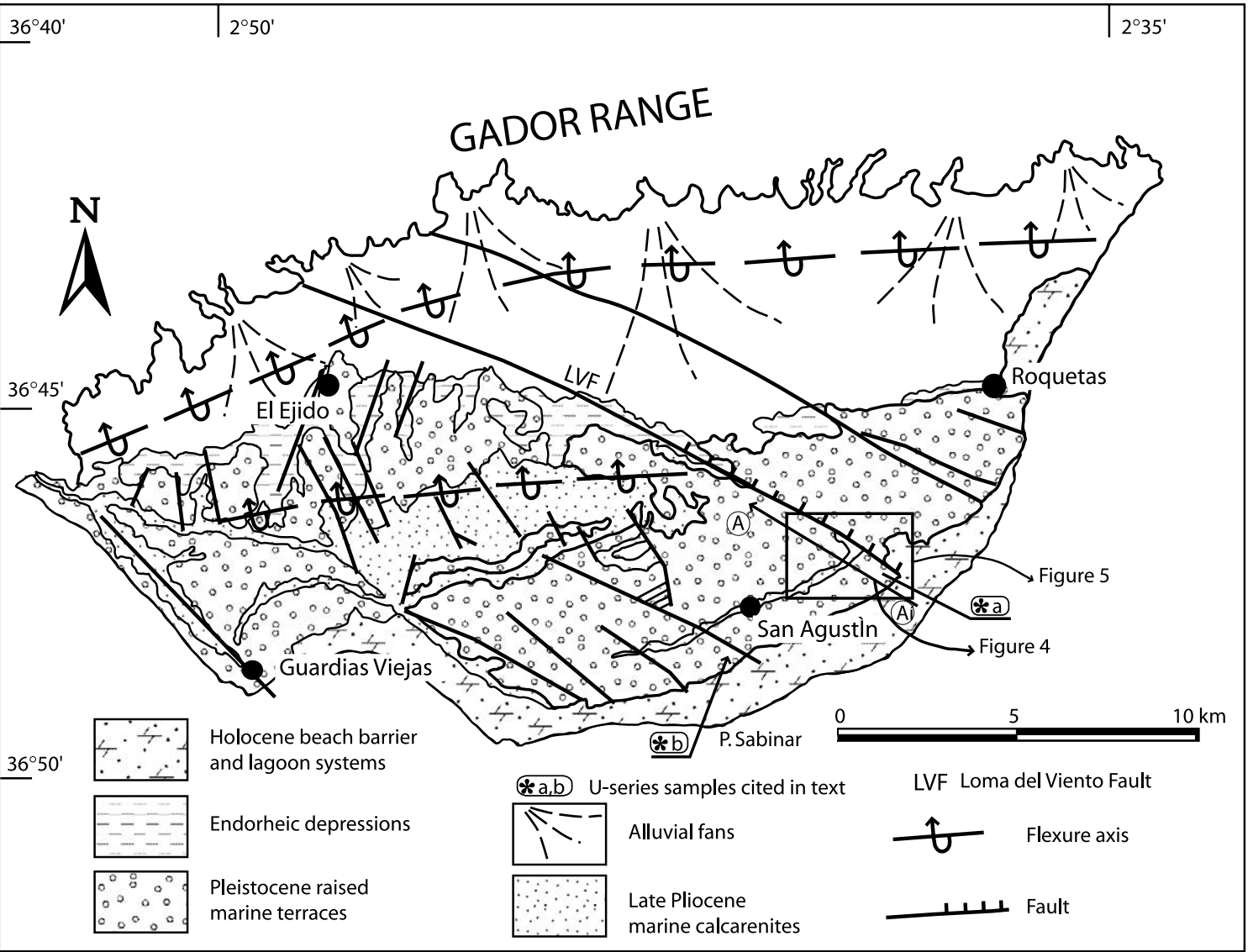

Fig. 3. Geological sketch of the Campo de Dalías (Almería), 1 in Fig. 2 (simplified from Goy and Zazo, 1982) and U-series samples: (a) UQT-315 and UQT-135; (b): UQT-140 and UQT-252 (Hillaire-Marcel et al., 1986).

of Quaternary sea level due to the well-formed terraces and excellent preservation of outcrops despite intensive agriculture that has obliterated most of the marine outcrops in the area in recent years.

We have distinguished a series of 27 marine terraces placed up to $82 \mathrm{~m}$ asl plus a system of Holocene spit bars along a transect normal to the coastline. As the transect is located in the upthrown fault block, we used photogrammetry and field data to distinguish terraces of tectonic origin due to fault movements from those of purely eustatic origin. To achieve this goal, we have considered only laterally continuous terraces that, some distance away from the fault scarp, exhibit a logical vertical sequence of sediments (shoreface, foreshore, backshore). Special atten- tion was paid to the height and lateral continuity of escarpments separating terraces and their identification on both sides of the fault. In this way we distinguished 16 marine terraces and one Holocene spit bar (Fig. 4) that form the base of the staircase arrangement clearly identified on stereoscopic aerial photographs (the more recent units have been depicted in Fig. 5).

Movements of the Loma del Viento fault result in different stratigraphical architectures: in the upthrown fault block marine units occur with a staircase arrangement that exposes the Pliocene substratum; in contrast, in the downthrown block marine units occur in offlap or (the older units) aggrade vertically. These facts also indicate that the movement of the fault was not constant and homogeneous. Displacements of 2, 3 and $10 \mathrm{~m}$ 


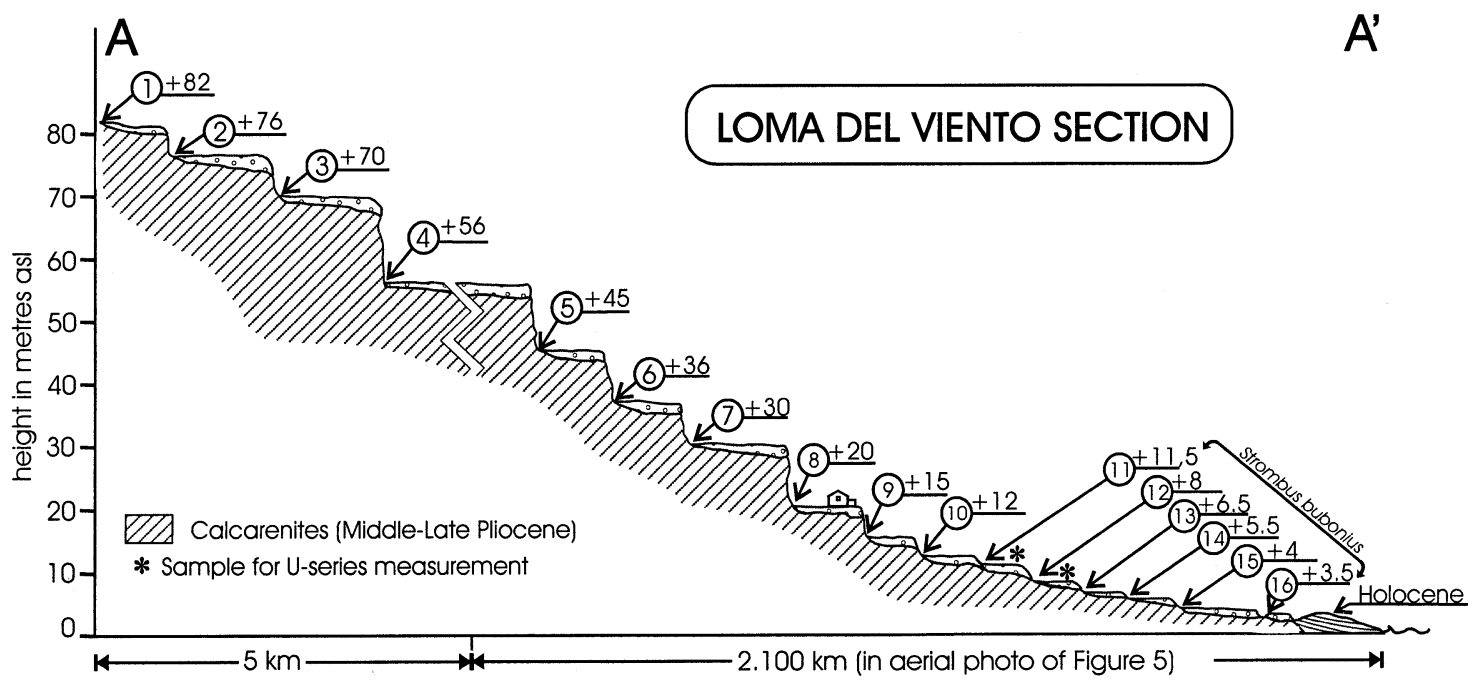

Fig. 4. Complete sequence of Pleistocene marine terraces in Loma del Viento (Almería), with indication of their heights in metres.

have been calculated for units 12,6 and 4 respectively.

The best preserved and most complete examples of marine terraces include a basal erosional surface related to a wave-cut platform, overlain by cemented, fossiliferous beach deposits with finingupward gravelly foreshore facies. The lower foreshore deposits include the plunge step, which contains the coarsest grain sizes and is indicative of the local mean sea level at the time of deposition in the western Mediterranean. The faunal content always consists of littoral species: Balanus sp., Ostrea edulis, Patella sp., Glycymeris glycymeris. In addition, the more recent terraces contain several abundant faunas (Thais haemastoma, G. glycymeris, Spondylus gaederopus, Conus mediterraneaus) including the warm 'Senegalese' fauna of Strombus bubonius and Cymatium dolarium. Warm faunas do not occur in Holocene deposits.

\subsection{Geochronological interpretation}

Four marine terraces bearing Strombus bubonius have been identified in the littoral of Almería based on stratigraphic, morphological and sedimentological criteria. Hillaire-Marcel et al. (1986) correlated these terraces with OIS 7a (ca. $180 \mathrm{ka}), 5 \mathrm{e}$ (ca. $128 \mathrm{ka}$ ) and 5c (ca. $95 \mathrm{ka}$ ) using $\mathrm{U}$-series dating. The youngest terrace found only in a few coastal localities was thought to represent OIS 5a, although it could not be dated accurately (Goy et al., 1986b). The stratigraphic architecture of deposits, and new detail mapping of units near the locality of Guardias Viejas used to locate very precisely the samples collected for U-series measurements, suggested three eustatic oscillations during OIS 5e (Zazo and Goy, 1989; Zazo et al., 1993).

Further U-series dating of a single marine terrace containing Strombus bubonius near Roquetas led McLaren and Rowe (1996, p. 716) to conclude that "there is isotopic evidence that many other published U-series mollusc ages from this region are also to be artefacts of open-system behaviour and therefore inaccurate. It is therefore not yet possible to positively identify from the available U-series data the time period or even the number of occasions during which the Senegalese fauna was present in the Mediterranean during the Middle and Upper Pleistocene". These authors suggested that the examined terrace corresponded to OIS $5 \mathrm{e}$.

Hearty et al. (1987) carried out AAR analyses in several places of the littoral of Almería including Guardias Viejas, not far from Loma del Viento (Fig. 3), where they sampled a marine deposit located $2 \mathrm{~m}$ asl (no figure is included in the paper) and included it in their 'aminozone E', or OIS 5e 


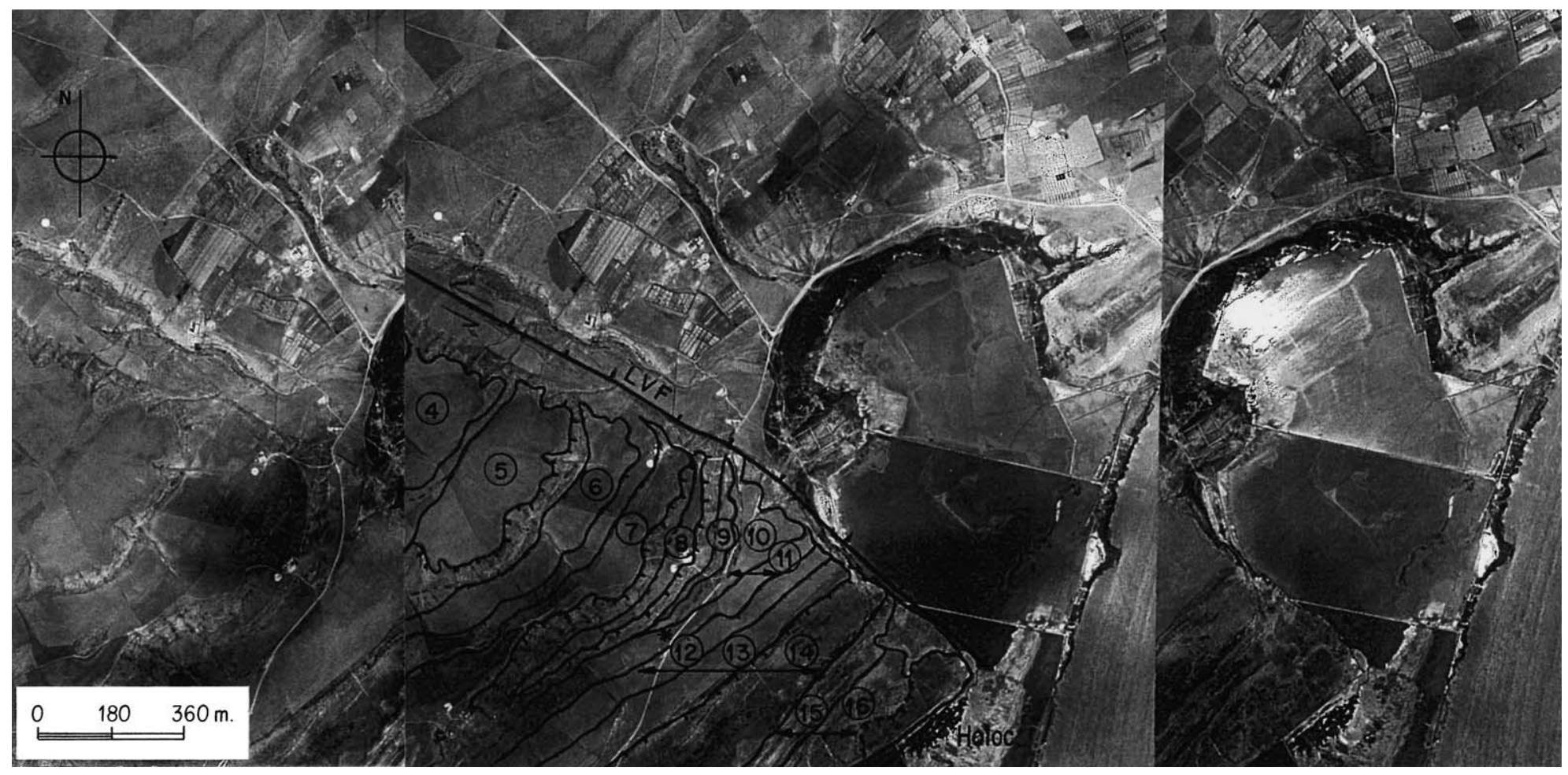

Fig. 5. Stereoscopic air photographs of Loma del Viento section (Almería) showing the more recent marine episodes (encircled numbers). (*): U-series samples (a in Fig. 3). 
(see Section 1). Hearty et al. (1987) calibrated the age of this aminozone as $143 \pm 7 \mathrm{ka}$ by U-series measured on a coral (Cladocora caespitosa) collected from a marine deposit containing Strombus in Cape Huertas (Alicante province).

Our present data suggest that the sequence of marine terraces is of Quaternary age because all terraces rest upon Middle-Late Pliocene calcarenites. As we have disregarded those terraces having a clear tectonic origin related to the Loma del Viento fault, probably all marine units numbered 1 through 16, and the Holocene spit-bar system that began to deposit at $6.9 \mathrm{ka}$ (Goy et al., 1996) should have been deposited during the highstands corresponding to interglacial periods.

Results of U-series measurements (HillaireMarcel et al., 1986) in Loma del Viento (a in Fig. 3) suggest ages $187+20.2 /-17 \mathrm{ka}$ (sample UQT-315 on Strombus bubonius) and 188+22.4/ -18.4 ka (sample UQT-135 on Glycymeris glycymeris) for terrace 11 (Figs. 4 and 5). U-series measurements (Hillaire-Marcel et al., 1986) carried out in terrace 12 at Punta Sabinar (b in Fig. 3) suggest ages $130.6+12.8 /-11.4 \mathrm{ka}$ (sample UQT140 on $S$. bubonius) and $131+14 /-12.2 \mathrm{ka}$ (sample UQT-252 on S. bubonius).

It is interesting to note that the fossil content of terraces 11 through 16 includes Strombus bubonius (Fig. 4); regardless of the problems posed by faunal reworking, palaeontological studies reveal the scarcity of the 'Senegalese' fauna in the oldest terrace, as compared with the relative abundance of such fauna in the most recent units (12 to 16).

Unfortunately, the papers by Hearty et al. (1987) and McLaren and Rowe (1996) lack exact maps and sections indicating the precise location of samples (the only reference is the elevation of sampling sites and the names of Guardias Viejas and Roquetas villages). Given the tectonic complexity of the area and the lateral change in the elevation of any given terrace observed in the field, it is very risky to apply the data in these papers to the terraces that we describe. In consequence we interpret our data (that have, at least, stratigraphic coherence) stating that terrace 11 formed during OIS 7, and terrace 12 during OIS 5e. We correlate the three highstands distinguished in Guardias Viejas during OIS 5e by
Zazo and Goy (1989) and Zazo et al. (1993) with terraces 12, 13 and 14 at Loma del Viento, meaning that the younger terraces 15 and 16 can be related to two highstands within an interstadial (5c and/or 5a). Isotopic data from Campo de Dalías area yield ages close to $5 \mathrm{c}$ (ca. $95 \mathrm{ka}$ ).

Inside the overall uplift trend recorded at Loma del Viento by 27 marine terraces, we think that there are some episodes of sudden uplift. However, the criteria listed before make it possible to consider that there are probably only 16 true eustasy-controlled terraces.

According to this and the palaeo-position of the sea level during OIS 5e (see Section 2), we have calculated an uplift rate of $0.046 \mathrm{~mm} / \mathrm{yr}$ in Loma del Viento area for the last $130 \mathrm{kyr}$. Calculations of uplift rates should not be extended too far back in time, because it is illusory to assume that fault movements and uplift of the upthrown fault block have been gradual.

\section{Cope Basin}

\subsection{Setting}

The Cope Basin is located in the Águilas Arc ( 2 in Fig. 2), and was generated by extensional tectonics roughly parallel to the main regional stress field (Bardají et al., 1999). The sea invaded the basin in the Early Pliocene depositing yellow calcarenites on the shallow shelf and blue-greenish marls in deeper parts. Palaeomagnetic and micropalaeontological data (Montenat et al., 1978; Bardají et al., 1995) indicate continuous marine sedimentation during the Pliocene and part of the Early Pleistocene. Then, there was a change to a more coastal setting with high-energy terrigenous sedimentation (both marine and terrestrial). We interpret that the change was caused by reactivation of faults limiting the basin along the surrounding ranges, but a climatic influence cannot be excluded.

\subsection{Cope Basin: Quaternary units}

Quaternary sedimentation in the Cope Basin occurred in a complex pattern due to the coinci- 


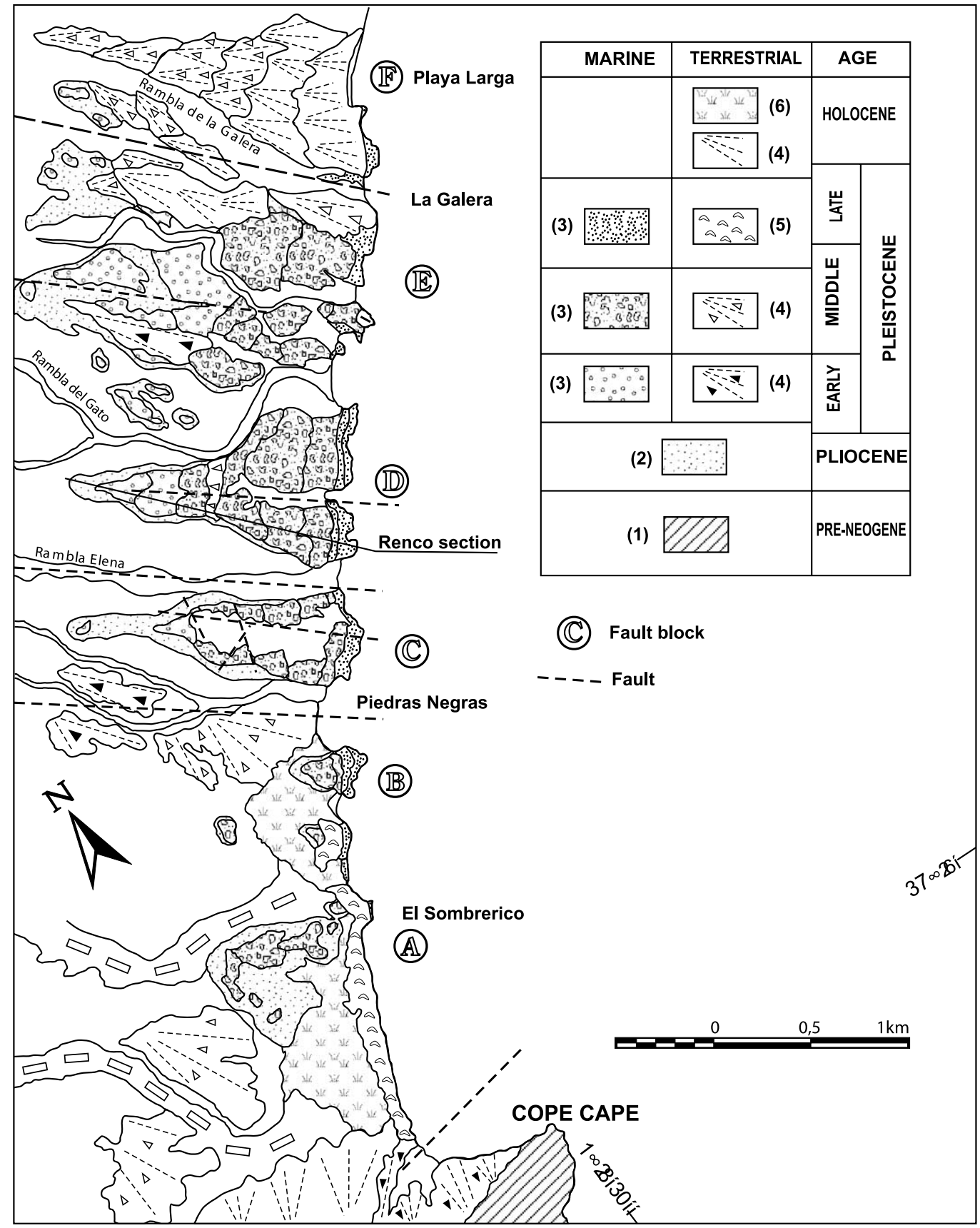

Fig. 6. Geological sketch of the Cope Basin (Murcia), 2 in Fig. 2, showing the main active faults controlling Pleistocene sedimentation. Key: (1) Betic basement; (2) yellow calcarenites; (3) conglomerates: Quaternary marine units; (4) alluvial fans; (5) dunes; (6) lagoon deposits (modified from Bardají et al., 1986). 
dence of: (1) active tectonics along $\mathrm{N} 60^{\circ} \mathrm{E}$ faults that marked the boundaries of the basin and created the uplift necessary for development of alluvial fans. Also faults directed $\mathrm{N} 120^{\circ} \mathrm{E}$ (Fig. 6), which are related to only minor subsidence, determined the lateral extent and morphology of the basins, the flow directions of the distributary channels and orientation of fans; and (2) repeated sea-level changes, which produced differential subaerial exposure and distinct sedimentary units. Sediment infilling has formed a series of rhomboidal delta-shaped deposits along the coast (Fig. 6). The most distinctive facies (Bardají et al., 1986; Goy et al., 1989; Dabrio et al., 1991; Zazo et al., 1998) are shallow-marine and coastal deposits comprising coarsening-upward conglomeratic, well-cemented beach deposits with Ostrea, Balanus and Glycymeris (highstand facies); and subaerial reddish alluvial-fan deposits consisting of conglomerates with imbricate pebbles, and massive sandy mudstones (lowstand facies). Large-scale, low-angle cross-bedding in the marine episodes indicates offlap and coastal progradation.

Pleistocene deposits rest in unconformity upon Pliocene sediments. Up to 10 marine units (numbered 1 to 10 ) have been identified with variable elevations and lateral extent owing to differences in the magnitude and timing of faulting along the coast (Fig. 7). Most of the marine units are separated by terrestrial deposits, but in some cases the only preserved records of sea-level fall and regression are erosional surfaces.

The more recent marine units $(8,9$, and 10) form a staircase cut into the older units (Fig. 7). Most probably, the shape and distribution of units was affected by uplift of the Águilas Arc (Fig. 2) taking place before deposition of unit 8 (Bardají et al., 1999). However, the deposits are readily identified by the occurrence of Strombus bubonius.

The deposits of unit 8 exhibit rapid lateral facies changes from marine to terrestrial. Deposits of unit 9 always overlap unit 8. Facies in deposits of unit 9 are conglomeratic to the north and oolitic to the south, where it forms a barrier-islandlagoon system with associated oolitic dunes near Cape Cope, the area of the basin that has experienced the greatest subsidence.
The deposits of the younger unit 10 occur on benches incised within deposits of units 8 and 9, forming the cited staircase of units. They comprise quartz sands rich in Strombus bubonius, passing landwards to cemented quartz aeolian dunes.

\subsection{Geochronological interpretation}

The most complete sequence was observed at Casa de Renco (Fig. 8, and D in Figs. 6 and 7), although the oldest unit does not crop out in this particular section. Palaeontological and palaeomagnetic data (Bardají et al., 1995) suggest that the Plio-Pleistocene boundary (1.8 Ma) occurs within the yellow calcarenites, and the Matuyama-Brunhes boundary (780 ka), marking the passage from Early to Middle Pleistocene, occurs within marine unit 4 . This means that at least six of these marine units are of Middle-Upper Pleistocene age. In contrast, Holocene deposits are poorly represented.

Given the lack of U-series dating in this basin, the only geochronological data come from palaeomagnetic series and sedimentary facies, particularly oolitic beach and aeolian dune deposits. Palaeomagnetic data suggest that six sedimentary units were deposited in highstand conditions during Middle-Upper Pleistocene interglacials and/or interstadials. The association of oolitic facies and Strombus bubonius has been correlated with the first peak of the last interglacial, OIS $5 \mathrm{e}$, in Almería and Alicante, not far away from Cope Basin (Goy et al., 1993b) using stratigraphic data and U-series dating (Causse et al., 1993). If this is the case, unit 9, the second unit bearing $S$. bubonius, would represent the first highstand of OIS 5e, whereas unit 10 (also bearing $S$. bubonius) would correspond to a second highstand inside the same substage. The older unit 8 , which bears a scarcer 'Senegalese' fauna, can be correlated with OIS 7. The tectonic behaviour of the Cope Basin during the Quaternary has been variable, and the number and topographic elevation of marine units found in the various parts depends on their position relative to the fault systems. Uplift rates up to $0.038 \mathrm{~mm} / \mathrm{yr}$ for the last $130 \mathrm{kyr}$ were calculated for the Casa de Renco area using the same criteria as indicated in Section 2. 


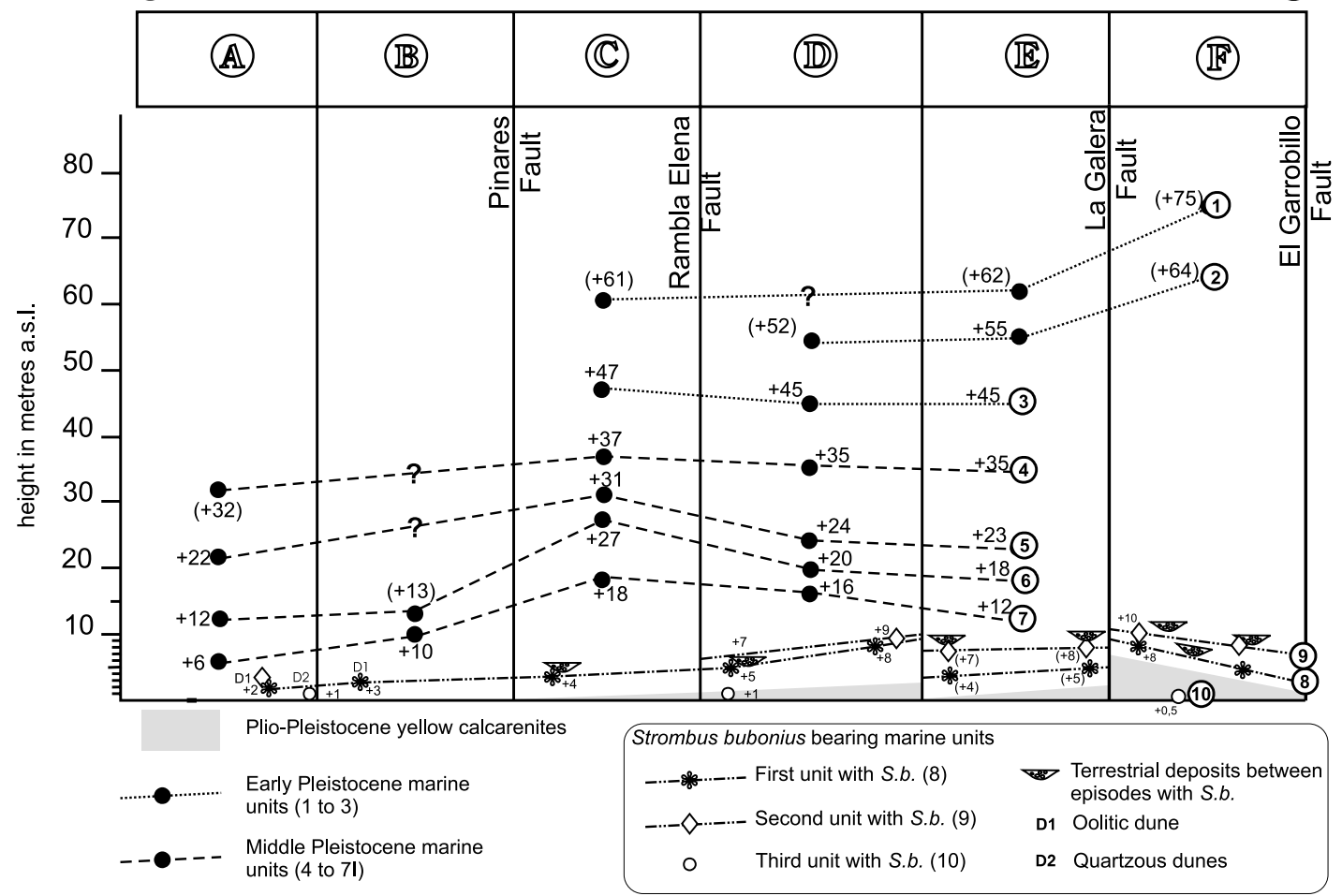

Fig. 7. Pleistocene marine units in the Cope Basin, showing the differential movement of fault blocks A to F (pictured in Fig. 6). Elevations asl in metres. Figures in brackets: no inner edge observed.

\section{La Marina}

\subsection{Setting}

The sequence of Quaternary deposits at La Marina is located in the Northern Terminal Splay of the 'Eastern Betics left lateral shear zone' (3 in Fig. 2). The tectonic structure of this zone includes an E-W-trending system of folds (Fig. 9) crossed by N-S normal faults (Goy et al., 1989). The Sierra del Molar range, just west of La Marina village, consists of yellow, fossiliferous marine

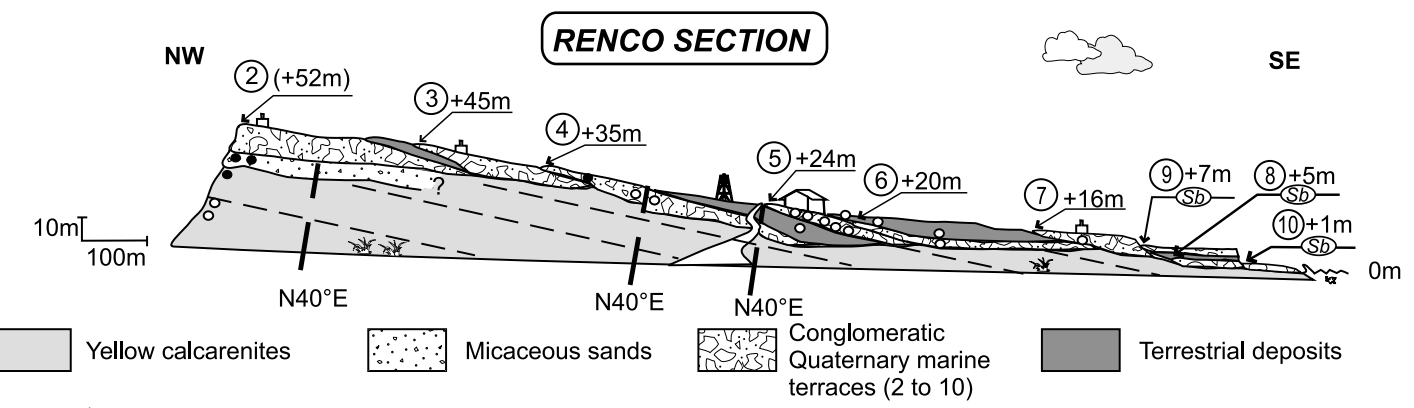

Normal fault o Normal polarity - Reverse polarity $\quad+20 \mathrm{~m}$ Topographic elevation $\begin{aligned} & \text { Tho } \\ & \text { above mean sea level }\end{aligned}$

Fig. 8. Marine and terrestrial units in Renco section, Cope Basin (D in Fig. 6). 


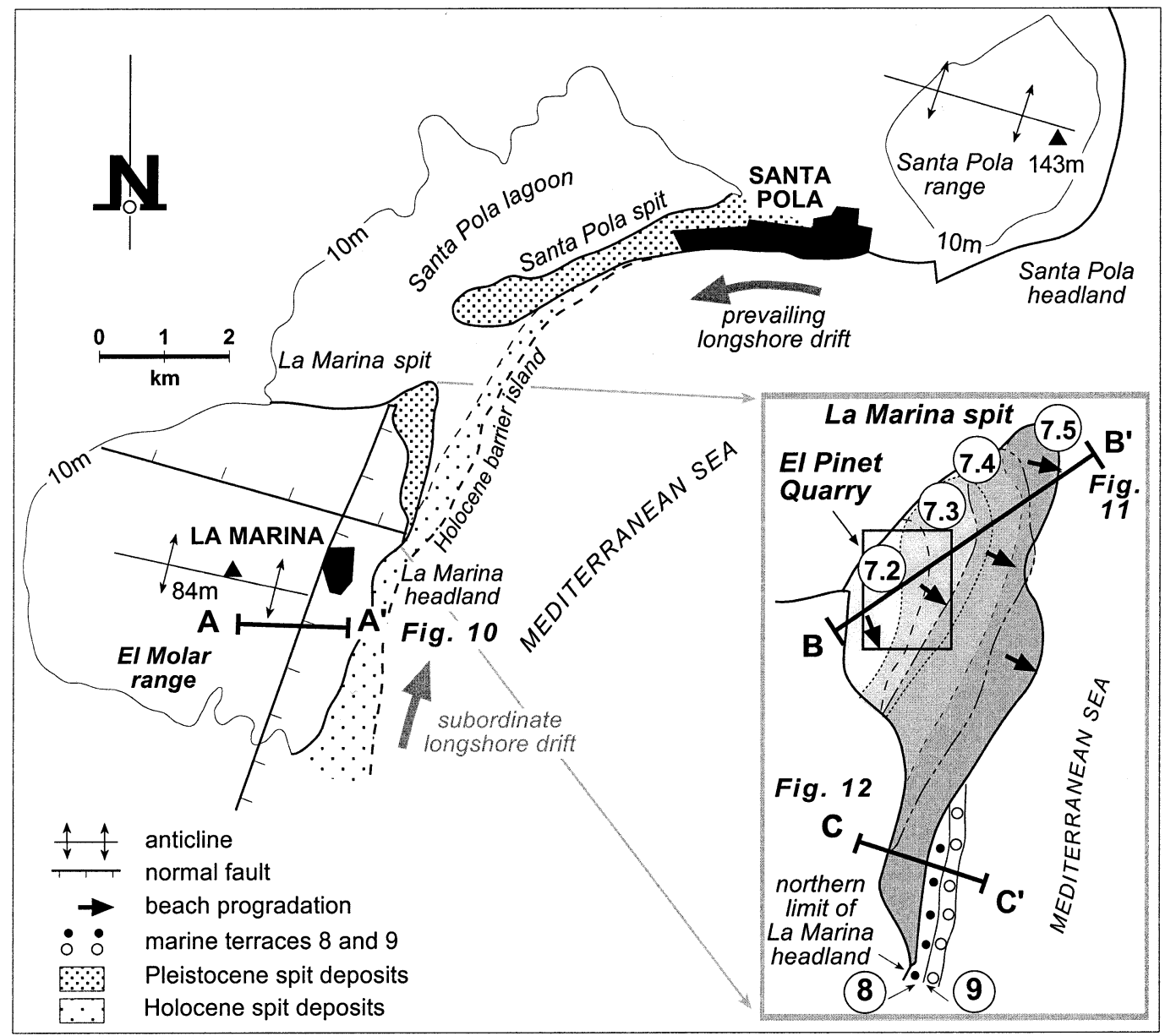

Fig. 9. Structural sketch of La Marina area (Alicante).

calcarenites (Late Pliocene) that grade upwards into fossiliferous sandstones with interbedded pink marlstones representing barrier island and lagoon environments of units 1 and 2 (Fig. 10). The succession is capped unconformably by silty distal alluvial-fan facies topped by a calcrete layer.

Tectonic activity and uplift along E-W-directed faults caused widespread regression during the Early Pleistocene. Later reactivation of N-S-directed faults and uplift of the El Molar range promoted the formation of a staircase-like system of marine terraces on the eastern flank of El Molar (Goy and Zazo, 1988, 1989; Goy et al., 1989). There are four major terraces (3 to 6) at elevations $+40 \mathrm{~m} \mathrm{(3),}+28 \mathrm{~m} \mathrm{(4),} \mathrm{+21} \mathrm{m} \mathrm{(5),} \mathrm{and} \mathrm{+12} \mathrm{m}$
(6). Terrace sediments consist of well-cemented conglomerates, up to $2 \mathrm{~m}$ thick, that change laterally into finer-grained gravelly foreshore and backshore facies rich in Ostrea, Balanus and Glycymeris. The youngest marine terrace (7) is a complex unit that bears Strombus bubonius.

\subsection{El Pinet quarry section}

At the northeastern border of the El Molar range, the $+12 \mathrm{~m}$ terrace has been displaced to $+8 \mathrm{~m}$ by an $\mathrm{E}-\mathrm{W}$-trending normal fault. After the faulting event, La Marina range became a headland in the upthrown block and served as an anchor for the La Marina spit that grew to the NNE because of littoral drift. The resulting 


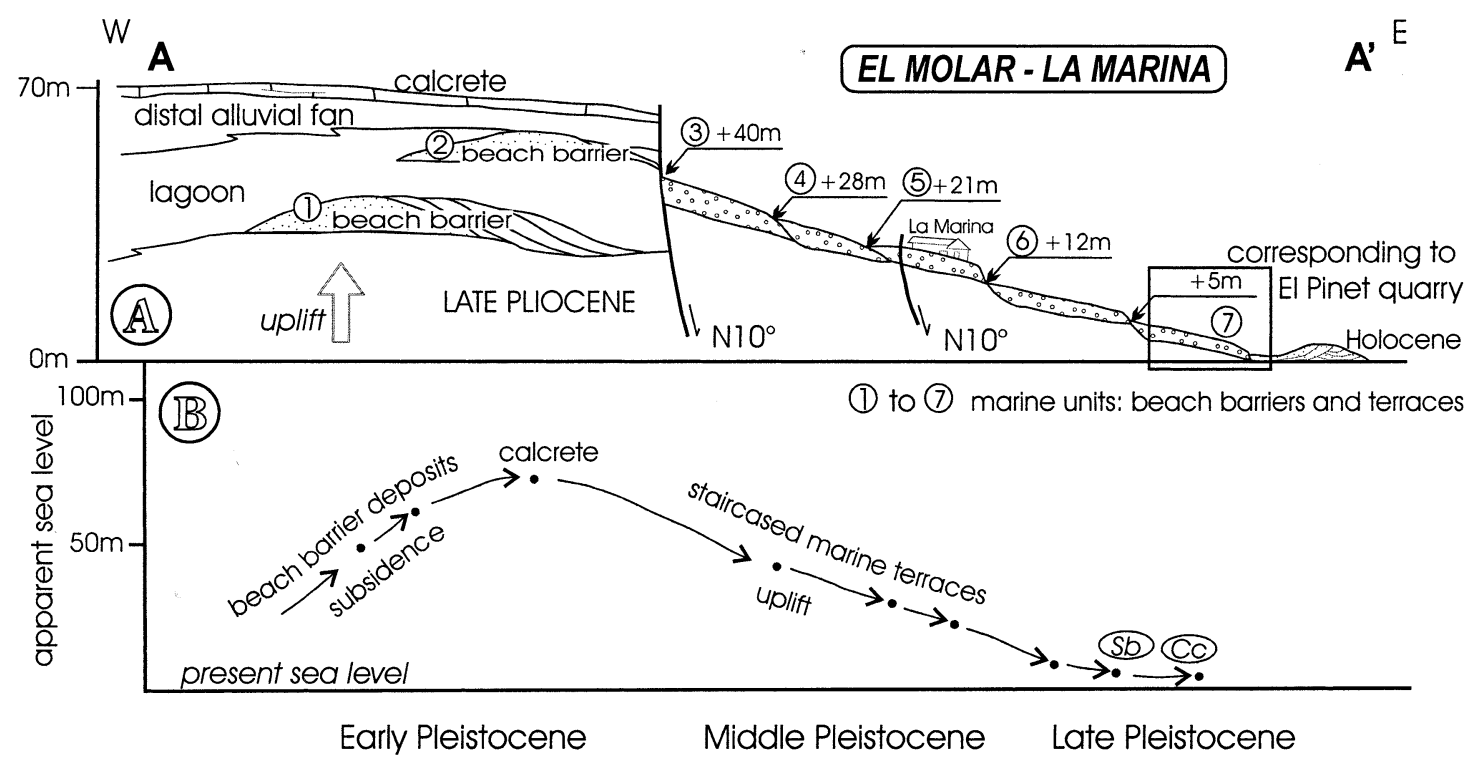

Fig. 10. (A) General cross-section from El Molar range to present sea level and (B) apparent sea levels during Pleistocene times suggested by the deposits outcropping in El Molar range, and their relations with the tectonic trend (modified from Goy et al., 1989). Sb, Strombus bubonius; Cc: Cladocora caespitosa; 1-7 marine units: beach barriers and terraces.

offlapping sequence of spit deposits is exposed at a small, abandoned quarry called 'El Pinet' (Fig. 11). Here, it is possible to distinguish five prograding units (numbered 7.1 to 7.5 because they pass laterally to unit 7 of El Molar-La Marina, Fig. 10) all bearing a 'Senegalese' fauna including Strombus bubonius, Conus testudinarius, Cantharus viverratus, etc.

Unit 7.1: It is only partly exposed, and consists of serpulid limestone, bioclastic limestone and small patches of the encrusting coral Cladocora caespitosa, a species found in shallow environments of the western Mediterranean since the Late Pliocene to present (Fornós et al., 1996).

Unit 7.2: Oolitic calcarenite. The cortex of oolites is aragonite. Most of the nuclei are quartz grains or faecal pellets (Montenat, 1973). As the thickness of the cortex is small compared with the diameter of the nucleus, a large part of these deposits can be described as coated grains. The massive, burrowed layer represents the shoreface; the overlying parallel and wave-ripple cross-laminated calcarenite layer corresponds to the zone of wave action; and the topping cross-bedded interval records active megaripple migration. Oolitic calcarenites interpreted as aeolian dunes crop out in a small quarry a few metres to the NW, and are likely genetically linked to unit 2 . We interpret the vertical sequence of facies as the result of progradation of the sublittoral zones of a beach barrier.

Unit 7.3: Siliciclastic sandstones and conglomerates that overlie an erosional surface. Sediments are parallel laminated with laminae gently sloping to the $\mathrm{SE}\left(110-120^{\circ} \mathrm{E}\right)$, grading laterally in that direction into planar cross-bedding. These beds represent foreshore and plunge-step facies separated by erosional unconformities likely related to coastal erosion during storms. There are also erosional surfaces inclined to the SE which identify offlapping units; those surfaces are similar to the accretion surfaces produced by beach progradation. A gentle relative rise of sea level of ca. 25$40 \mathrm{~cm}$ is inferred based on a comparison of successive positions of the mean sea level as recorded by the plunge-step facies.

Unit 7.4: Calcarenites with some coated grains and oolites, which overlie an erosional surface. Accretion surfaces similar to those found in the former unit indicate progradation to the SE (130$\left.150^{\circ} \mathrm{E}\right)$.

Unit 7.5: This unit overlies an erosional surface 


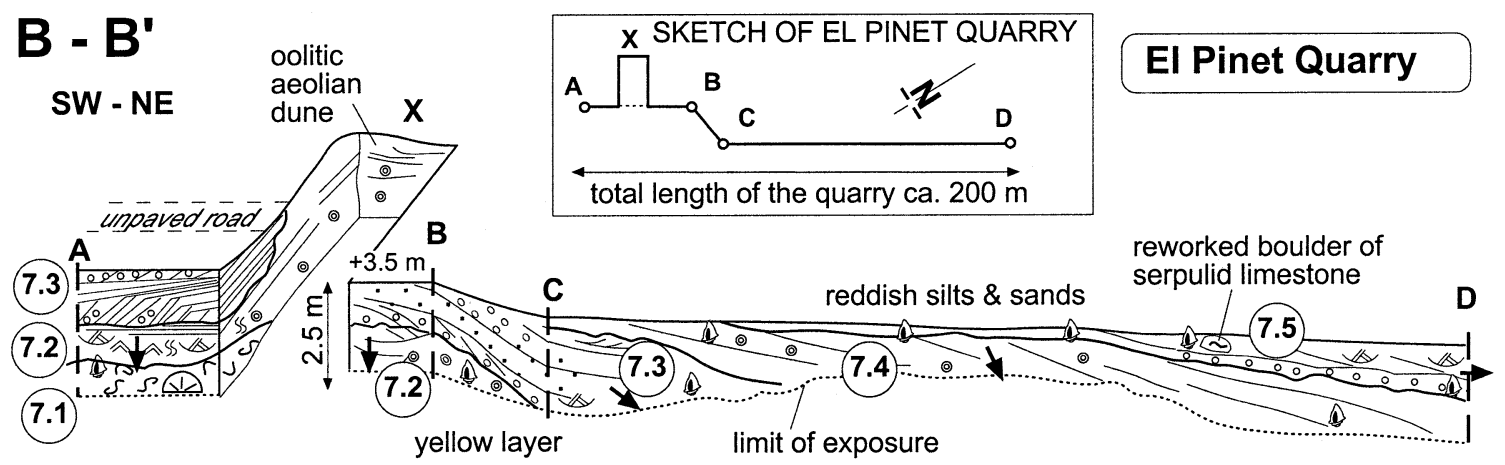

Key in Fig. 12

Fig. 11. Cross-sections of marine units, included in terrace 7 (in Fig. 10) at El Pinet quarry (modified from Zazo et al., 1998). See legend in Fig. 12.

traceable along the entire quarry exposure. This unit consists of calcarenites, sandstones, conglomerates with fragments of volcanic rocks and shells, and it is also the richest in Strombus bubonius shells. Internal accretion surfaces indicate progradation to the east. Large boulders of the underlying units are very abundant, and it is also characterised by a red matrix of sandy mudstone.

Two narrow, but laterally continuous, marine terraces (numbered units 8 and 9) formed by fossiliferous conglomerate occur encased into the Pleistocene spit bar, but no 'Senegalese' fauna has been found so far. Unit 8 is cemented, while unit 9 is not.

\subsection{Geochronological interpretation}

Geological, micropalaeontological and palaeomagnetic data (Montenat, 1973; Goy et al., 1989) suggest an Early-Middle Pleistocene age for the series of staircase-like terraces 3 to 6 of El MolarLa Marina section (Fig. 10), that are older than those containing Strombus bubonius.

Numerous workers have attempted to determine the age of the marine episodes found in $\mathrm{El}$ Pinet quarry (Fig. 11) using a variety of dating techniques. Bernat et al. (1982) carried out 12 U-series measurements largely on Strombus bubonius shells, and reported ages ranging from 150 to $65 \mathrm{ka}$, with five of the values clustered around $98 \pm 5.8 \mathrm{ka}$. These results led these authors to consider that the marine deposits of the quarry (oo- litic or not) correspond to OIS 5c. Hearty et al. (1987) carried out AAR analyses on the marine deposits at El Pinet quarry. These authors distinguished only two marine units (lower and upper) but unfortunately did not include lithological descriptions or cross-sections, just the elevations of sites where samples were collected. They date the lower unit as aminozones $\mathrm{E}$ and $\mathrm{F}$, and consider that the upper unit is aminozone $\mathrm{E}$. The origin of aminozone $\mathrm{F}$ is explained by faunal reworking from a unit submerged below present sea level (bsl) during the time of aminozone E. They concluded that the age of the marine units at El Pinet quarry is aminozone $\mathrm{E}$ (OIS 5e).

Two U-series measurements on mollusc shells (Glycymeris glycymeris and a bivalve) collected from the oolitic deposits of unit 7.2 and another from the non-oolitic deposits of unit 7.3 (Fig. 11) led Causse et al. (1993) to suggest an open chemical U-Th system. However, stratigraphic and sedimentological data across the outcrop at El Pinet quarry made the same authors (Goy et al., 1993b) suggest the probable existence of three distinct highstands with ages OIS 5e (oolitic), 5c (non-oolitic), and probably 5a (a terrace encased inside the former, represented by unit 8 in this paper, Fig. 12).

Our recent studies in the area revealed the existence of a unit (unit 7.1) below those described before. The faunal content includes Strombus bubonius and Cladocora caespitosa (Figs. 11 and 12). U-series measurements on the coral (Table 1) 


\section{C - C'}

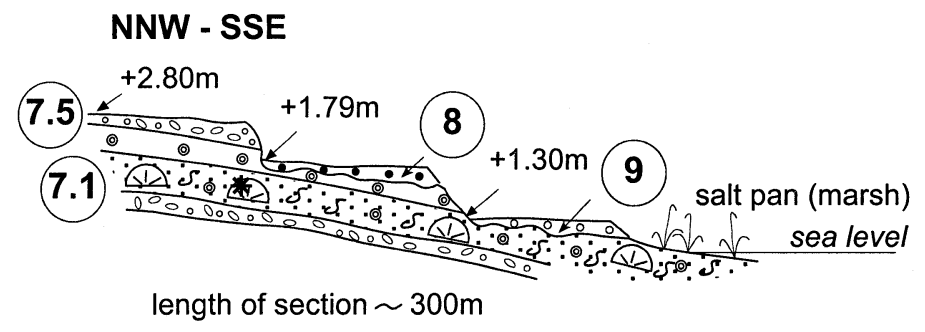

Key for figures $11 \& 12$
Fig. 12. Small, low-lying marine terraces cutting into deposits pertaining to marine units 7.1 to 7.5. yield 178.2+9.8/-8.9 ka, compatible with OIS $7 \mathrm{a}$. Thus, the remaining units $(7.2,7.3,7.4,7.5$, Fig. 11) could correspond to three highstands in OIS $5 \mathrm{e}$, the oldest represented by the oolitic facies (unit 7.2), the middle by mainly siliciclastic facies (units 7.3 and 7.4), and the most recent (unit 7.5) marked by high-energy deposits probably related to periods of increased storminess. The younger, encased unit 8 (Fig. 12) is a fossiliferous conglomerate of clasts reworked from the former Pleistocene units. It does not include $S$. bubonius, and can be correlated with a highstand during late OIS $5(5 \mathrm{c} / 5 \mathrm{a})$. The poorly cemented youngest terrace (unit 9, Fig. 12) is correlated with the Holocene given its stratigraphic position.

Geological and tectonic analyses of the El Molar-La Marina area (Fig. 10) suggest a change in the trend of vertical movements during the Quaternary from subsidence during deposition of the older marine units to uplift and deposition of the staircased terraces (Fig. 10A,B). This conspicuous change can be correlated with the tectonic reactivation that took place between the Early and Middle Pleistocene, widely recognised in all the eastern Betic Ranges (Zazo and Goy, 1989; Goy et al., 1989; Somoza, 1993; Silva et al., 1993).

Taking into account that: (1) terrace at $+12 \mathrm{~m}$ (unit 6) can be traced laterally to the neighbourhood of El Pinet quarry where it lies at elevation $+8 \mathrm{~m}$, (2) the complex terrace at $+5 \mathrm{~m}$ (unit 7) is a lateral equivalent of marine units 7.1 through 7.5 found at El Pinet quarry, and (3) palaeo-sea level during OIS 5e was $2 \mathrm{~m}$ asl (see Section 2), we calculated that the uplift range for the last 130 kyr was $0.023 \mathrm{~mm} / \mathrm{yr}$ in El Molar-La Marina, and $-0.003 \mathrm{~mm} / \mathrm{yr}$ in El Pinet quarry.

\section{Balearic Islands - Mallorca}

\subsection{Setting}

The most complete sequence of marine units occurs in the Palma Basin on the western coast of Mallorca Island (Fig. 13). During the Late Miocene, major faults transformed the large-scale geological structure of the island into a system of horsts and semigrabens that became independent basins at the beginning of the Quaternary to form the present basins of Palma, Inca and Sa Pobla along a NE-SW-trending trough (Del Olmo and Alvaro, 1984; Benedicto et al., 1993).

This paper describes the sections of Campo de Tiro and Cala Blava, located in the Palma Basin (Fig. 13) that is limited by two main fault systems directed NNE-SSW (Palma fault) and NE-SW (Sineu-Algaida and Enderrocat faults). Both systems acted as normal faults at least during the Quaternary and extend into the sea as recorded in high-resolution seismic profiles (Díaz del Rio et al., 1993).

Many papers have studied the Quaternary marine units, and their relations with terrestrial deposits in Mallorca aimed at recognising glacialinterglacial cycles and to establish the stratigraphic framework (Butzer and Cuerda, 1962; Butzer, 1975). Cuerda (1989) thoroughly studied the pa- 
Table 1

U-series results from shells of Strombus bubonius (Sb), Patella (P) and Thais $(\mathrm{Th})$ and coral Cladocora caespitosa (Cc) in marine units (1, 2, ...) and figures referred to in the text

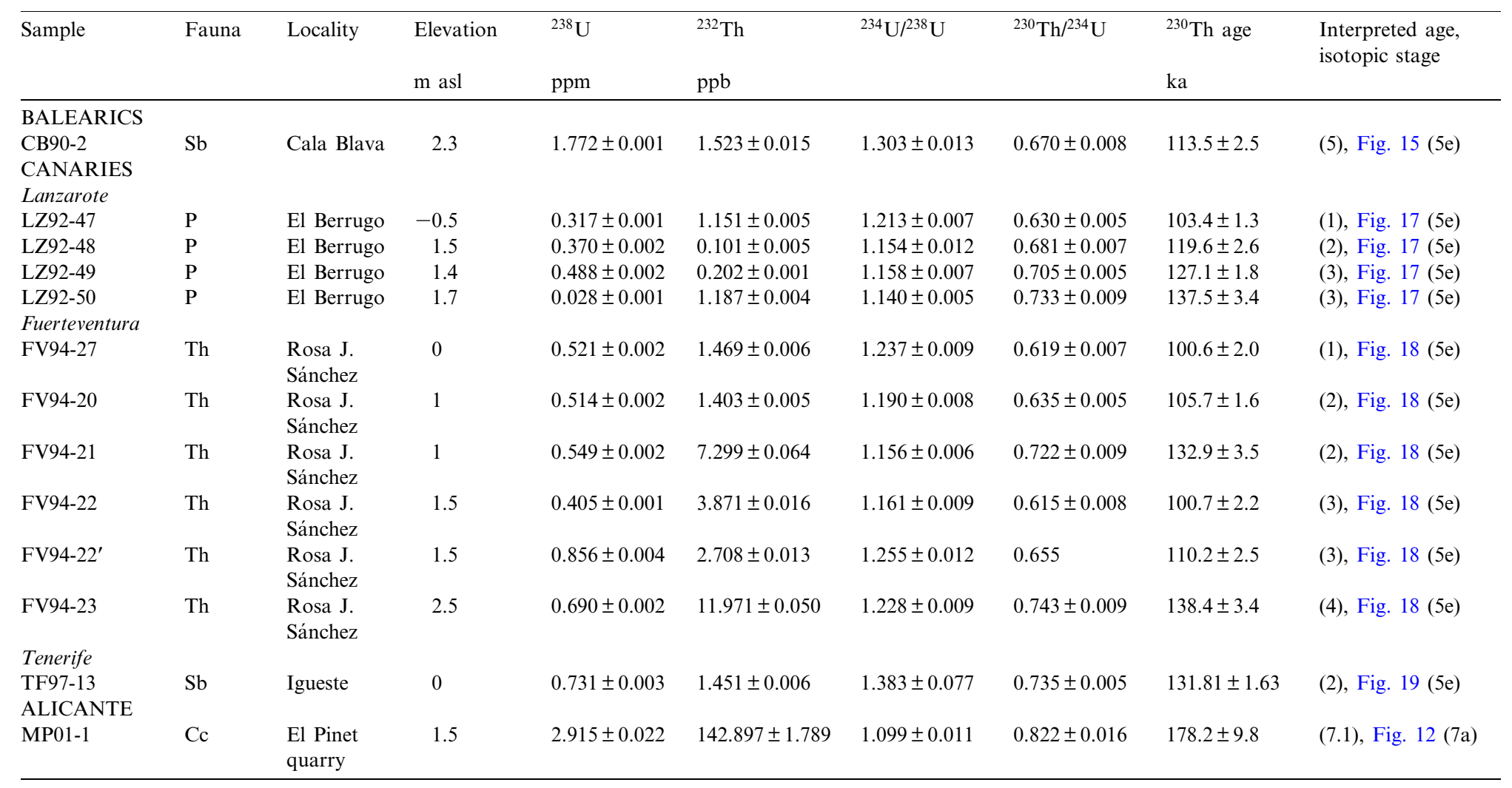

Analyses using TIMS technique, and results quoted with \pm 2 standard error. 


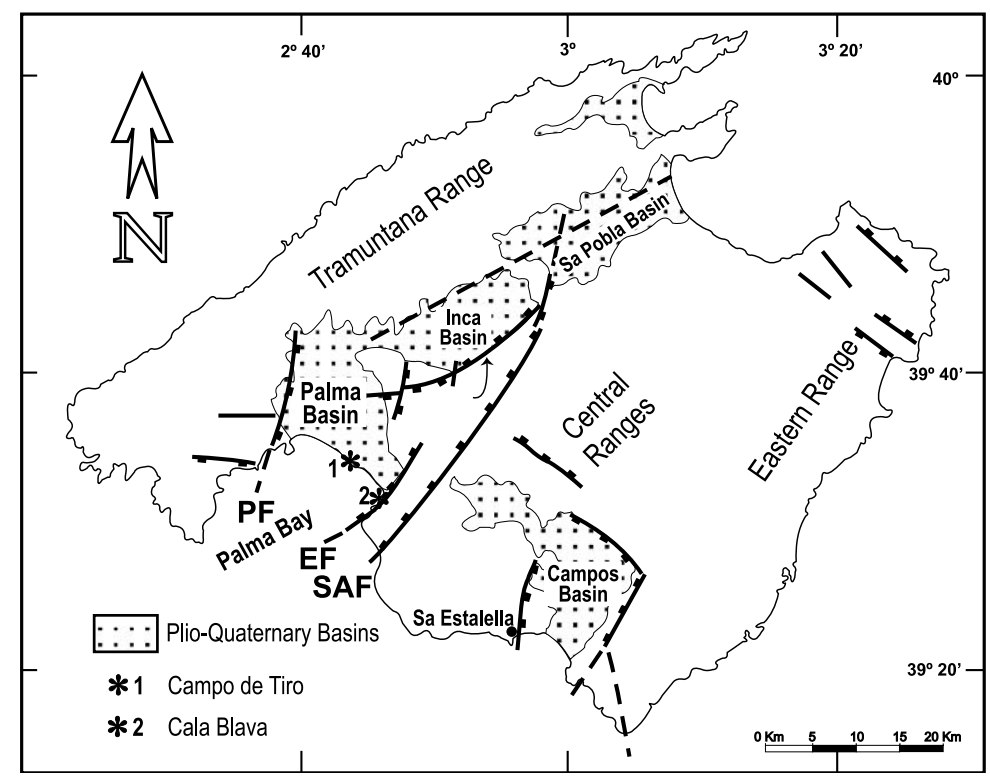

Fig. 13. Location map of studied sections at Mallorca Island (Balearic Islands). PF: Palma fault; EF: Enderrocat fault, SAF: Sineu-Algaida fault.

laeontology of the marine units presenting in addition a synthesis of the stratigraphy, isotopic dating, and good, abundant illustrations. Stearns and Thurber $(1965,1967)$ first applied U-series measurements in the island using marine deposits containing Strombus bubonius. In addition, AAR analyses in marine and terrestrial deposits of Mallorca Island led Hearty (1987) to define four aminozones (A, C, E, F-G) using similar criteria as Hearty et al. (1986) for the western Mediterranean (see Section 1). In Mallorca four aminozones were distinguished (A, C, E and F-G). A relates to the Holocene transgression and aminozone $\mathrm{C}$ to a mid to late isotopic stage 5 event $(90 \pm 15 \mathrm{ka})$ revealed only by supralittoral aeolianites. Calibration of aminozone $\mathrm{E}$ was provided by a $129 \pm 7 \mathrm{ka}$ U-series coral age on Cladocora caespitosa from Son Grauet (Palma Bay). As most times it was impossible to distinguish aminozones $F$ from $G$, Hearty (1987) considered them a single group $(\mathrm{F}-$ G). More recently, Hillaire-Marcel et al. (1996) concentrated the analyses on U-series in Campo de Tiro (Bay of Palma) whereas Goy et al. (1997) dated Holocene marine deposits in Mallorca using ${ }^{14} \mathrm{C}$ and stated that the maximum of the present interglacial began c. $7.1 \mathrm{ka}$.

\subsection{Campo de Tiro}

Four marine units (1 to 4) are separated by reddish terrestrial deposits or erosional surfaces between elevations of $3 \mathrm{~m}$ asl and present sea level (Fig. 14). The substratum of the Campo de Tiro sequence is made of reddish clayey-silty terrestrial deposits that include clasts of the underlying aeolian dune $\left(D_{1}\right)$, interpreted as red soils reworked during the transgression that deposited unit 1 .

The transition of the marine units to terrestrial deposits is not exposed due to covering by recent aeolian dunes (Fig. 14). However, red soils such as those visible on dune $\mathrm{D}_{2}$ seem to be related to the last interglacial or older interglacials as suggested by Rose et al. (1999). Soils formed in more recent times are brown.

The two older units (1 and 2) occur superimposed and consist of fossiliferous calcarenite with scattered pebbles that represent a foreshore facies. They are separated by an intervening layer of red silt containing angular clasts eroded from cemented aeolianites and caliches of the underlying aeolian dunes. Both units (but particularly unit 2) contain abundant warm fauna (Brachidontes senegalensis, Cantharus viverratus, Conus testudina- 


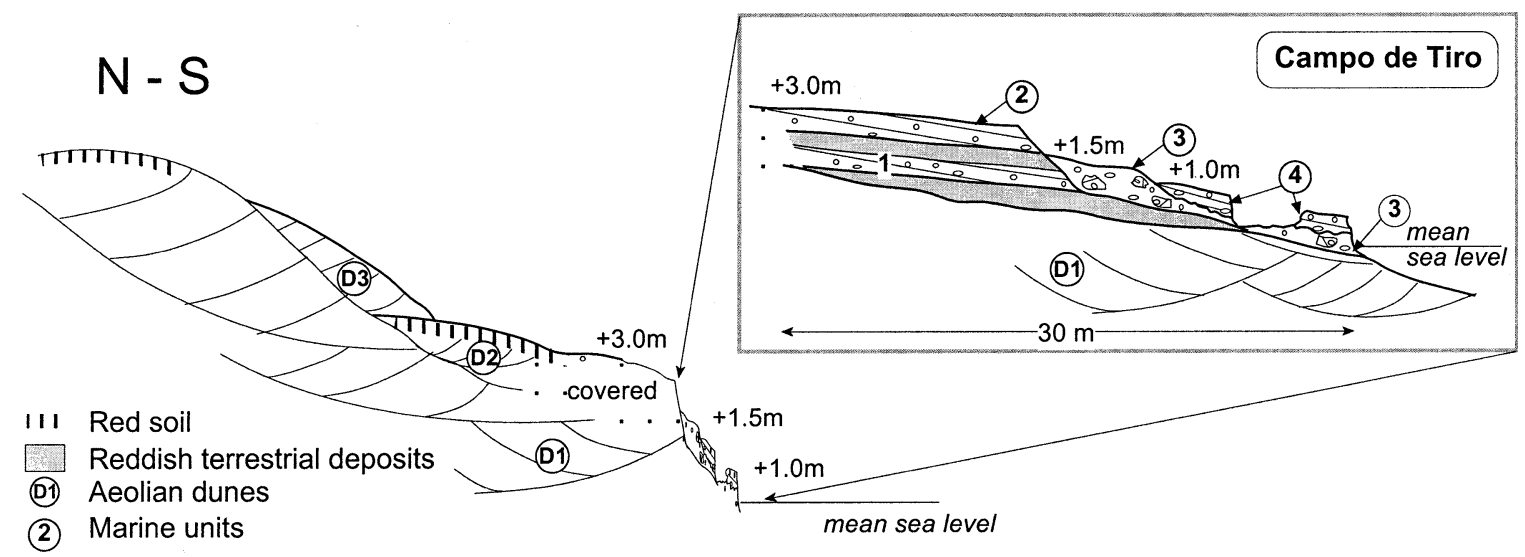

total length of section aprox. $600 \mathrm{~m}$

Fig. 14. Marine units and terrestrial deposits in Campo de Tiro (Mallorca).

rius, Cardita senegalensis, and Strombus bubonius) of the 'Senegalese' type (Cuerda, 1989).

Unit 3 rests on an erosional surface that cuts unit 1 and, laterally, also unit 2 . It consists of well-cemented, angular, large (mean diameter $0.5-1 \mathrm{~m}$ ) blocks derived from units 1 and 2, plus rounded pebbles derived from older calcareous units deposited in beach settings (foreshore to upper shoreface), all of them embedded in a reddish clay-silt matrix. While unit 3 contains a warm-water fauna, Strombus bubonius is absent (Cuerda, 1989).

The youngest deposit, unit 4, consists of beach conglomerates and overlies an erosional surface on unit 3. The faunal content is not of the warm type, but similar to the present except for the occurrence of Acar plicata, a species not found in Holocene deposits of Mallorca (Cuerda, 1989; Goy et al., 1993a, 1997).

\subsection{Cala Blava}

The site is located at the southern border of the Bay of Palma, on the downthrown block of the Enderrocat fault (Fig. 13). Six marine units can be distinguished along the coastal cliff between Cape Orenol (some $400 \mathrm{~m}$ north of Cala Blava) and Torrente (creek) de Cala Mosques, $100 \mathrm{~m}$ to the south of Cala Blava.

Marine unit 1 stands $10 \mathrm{~m}$ asl (Fig. 15) and includes an abrasion platform cut into aeolian dune deposits. The aeolianite is overlain by a layer of well-cemented conglomerate, less than $0.5 \mathrm{~m}$ thick, with marine bioclasts. A road crossing the platform obliterates a part of this layer in the reference section but at Cape Orenol the equivalent unit contains a 'Senegalese' fauna of Strombus bubonius, Cantharus viverratus and Barbita plicata (Cuerda, 1989; Cuerda and Sacarés, 1992).

Unit 2 consists of well-cemented sandstone and reddish siltstone filling a notch related to a poorly developed platform or bench. The faunal assemblage is analogous to that found today in the Mediterranean. The $\mathrm{D}_{3}$ aeolian dune represents the lowstand facies following the highstand that reached up to $6.5 \mathrm{~m}$ asl (Fig. 15).

Unit 3 is represented by a continuous notch with thin deposits of a marine conglomerate. There are three younger marine units $(4,5,6)$ that form a staircase cut into the lower part of the older sequence. Facies and faunal contents in these three units are similar to units 1,2 and 3 described in Campo de Tiro, but units 4 and 5 are separated by an erosional surface (instead of terrestrial deposits) in Cala Blava (Fig. 15).

\subsection{Geochronological interpretation}

We will deal with the chronology of Campo de Tiro in the first place owing to the large number of U-series data, and the similarity with the sec- 


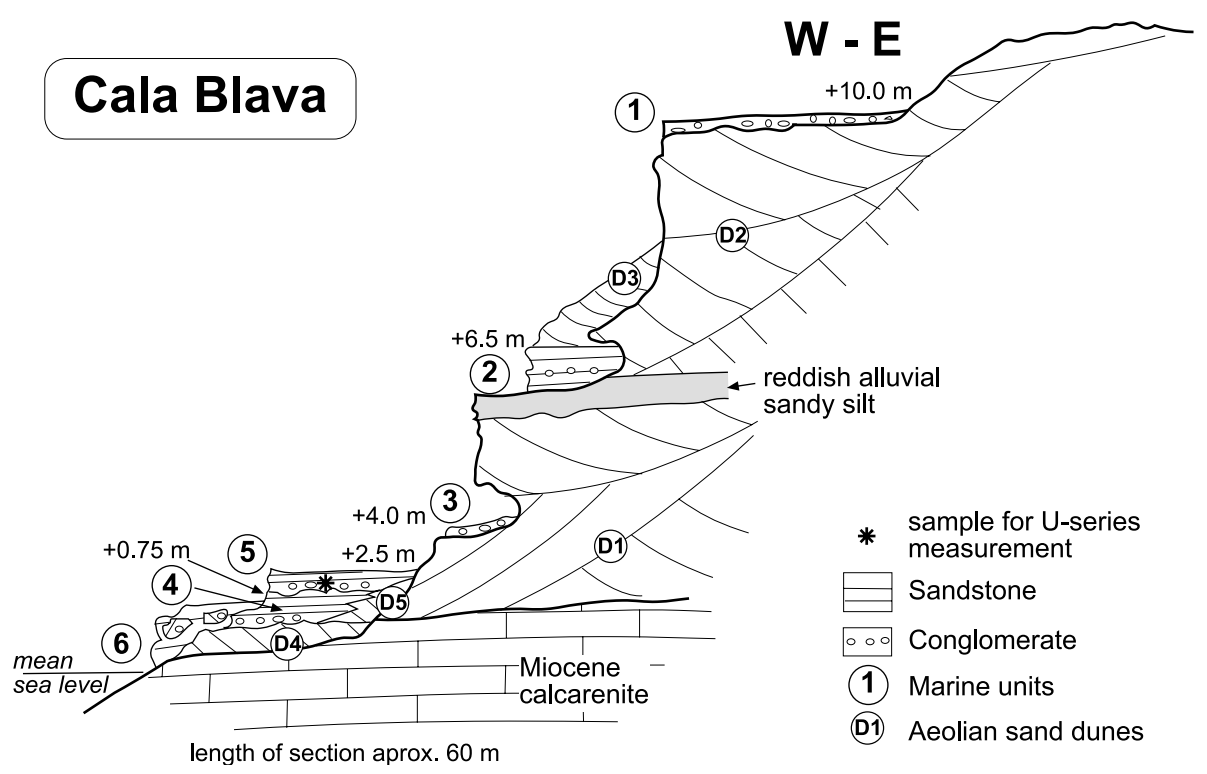

Fig. 15. Marine units and terrestrial deposits in Cala Blava (Mallorca).

tion at Cala Blava. The first U-series data obtained from unit 3 (Stearns and Thurber, 1965) suggested an age of ca. $75 \mathrm{ka}$.

Hearty (1987) identified three marine units in Campo de Tiro which, according to his figure and description (fig. 3, p. 248), correspond to units 1,2 , and 3 in the present paper. All these fall into aminozone $\mathrm{E}$ (OIS 5e) although he points to the possibility that unit 3 may be somewhat younger (OIS $5 \mathrm{c}$ or $5 \mathrm{a}$ ).

Hillaire-Marcel et al. (1996) carried out 34 U-series analyses (TIMS) on mollusc shells in this locality; their data suggest that the three older units correspond to two highstands during OIS 5e: unit 1 (ca. $135 \mathrm{ka}$ ), units 2 and 3 (ca. $117 \mathrm{ka}$ ), and unit 4 (a scatter of ages around $100 \mathrm{ka}$ ).

However, stratigraphic, sedimentological, and faunal data suggest that three highstands during OIS $5 \mathrm{e}$ are recorded at the section. The highstand deposits are separated by lowstand phases and terrestrial deposits intercalated between units 1 and 2, and strong erosion that makes unit 3 to occur incised into the previous units. The facies and faunal content of unit 3 suggest that it is to be included in a different highstand. Along the southern coast of the island, there is also widespread evidence of changes in marine dynamic conditions such as: (1) the disappearance of part of the 'Senegalese' fauna, particularly Strombus bubonius, and (2) the occurrence of boulder deposits which provide evidence of high-energy conditions related to strong wave action.

Unit 4 represents an independent highstand as demonstrated by the disappearance of the 'Senegalese' fauna; however, it is of pre-Holocene age. Therefore, it seems reasonable to assume that it corresponds to OIS $5 \mathrm{c}$ or $5 \mathrm{a}$.

The three youngest units at Cala Blava $(4,5,6)$ correlate well with units 1,2 , and 3 from Campo de Tiro. U-series measurements (TIMS) in a sample from unit 5 yields an age of $113 \pm 2.5 \mathrm{ka}$ (Table 1).

Stearns and Thurber (1965) dated unit 2 of Cala Blava as $\geq 250 \mathrm{ka}$ using U-series measurements. The oldest terrace at Cala Blava (unit 1, elevation $10 \mathrm{~m}$ asl) is correlated with the $+11.5 \mathrm{~m}$ terrace of Cape Orenol, rich in 'Senegalese' fauna dated as $125 \pm 10 \mathrm{ka}$ by Stearns and Thurber (1967). These facts led Cuerda (1989) and Cuerda and Sacarés (1992) to suggest a last-interglacial age for this unit. On the other hand, Hearty (1987, fig. 7) included the terrace at $+11.5 \mathrm{~m}$ of Cape Orenol in aminozone $G$ with an apparent age $>300 \mathrm{ka}$.

Considering that the three sites (Campo de Tiro, Cape Orenol and Cala Blava) are located 
on the downthrown block of the Endecorrat fault that forms the Bay of Palma (Fig. 13) facing a low-energy coast, the sedimentary sequence at Cala Blava, and the differences in elevation $(7 \mathrm{~m})$ between the two groups of marine units containing the 'Senegalese' fauna, clearly suggest a prelast-interglacial age for unit 1 of Cala Blava and its equivalent at Cape Orenol. This means that these sites record the arrival of the warm fauna including Strombus bubonius in the Mediterranean Sea before the last interglacial. Therefore, it seems likely to ascribe unit 1 to OIS 11 or perhaps OIS 9 considering that there is record of two highstands (units 2, and 3) between unit 1 and those representing OIS $5 \mathrm{e}$.

The island of Mallorca is tectonically unstable as revealed by the elevations at which the lastinterglacial deposits are exposed along the coast depending on their location in grabens (for instance, the sites in the Bay of Palma described in this paper) or horsts (for instance Sa Estalella, Fig. 13). Units 1, 2, and 3, found in Campo de Tiro (Bay of Palma) at elevations of 3, 1.5, and $1 \mathrm{~m}$ asl, occur at Sa Estalella at elevations of 12, 6.5, and $2.5 \mathrm{~m}$ asl respectively (Goy et al., 1993a), witnessing uplift rates of $-0.007 \mathrm{~mm} / \mathrm{yr}$ for the Bay of Palma and $0.076 \mathrm{~mm} / \mathrm{yr}$ for Sa Estalella during the last $130 \mathrm{kyr}$ using the criteria cited repeatedly before. The variable elevations were first explained as the result of differences in wave energy between the two coastal segments (Hearty, 1987). However, the actual differences are not big enough to support the idea, although waves up to $5 \mathrm{~m}$ high have been recorded in $\mathrm{Sa}$ Estalella during extreme winter storms. Consequently, tectonic factors may be the main reason for the elevation of OIS 5e marine units.

\section{Canary Islands}

\subsection{Setting}

The Canary Islands (Fig. 1) are located in the Atlantic Ocean, $125 \mathrm{~km}$ off the northwestern coasts of Africa. We describe sections located on the islands of Lanzarote, Fuerteventura and Tenerife (Fig. 16).
Most papers dedicated to marine Quaternary terraces refer to sites in Lanzarote and Fuerteventura islands where they occur well exposed and include rich faunal contents. Driscoll et al. (1965), Lecointre et al. (1967) and Hernández-Pacheco (1969) pointed out that Strombus was present in almost all the marine terraces. The palaeontology of the terraces was studied by Meco (1977) who stated the occurrence of two species of Strombus: Strombus coronatus and Strombus bubonius, considering the first as characteristic of the Lower Pliocene and the last (a component of the 'Senegalese' fauna) as exclusive of the last interglacial.

Radtke (1985) applied U-series measurements and electron spin resonance to marine terraces bearing Strombus bubonius in Fuerteventura and obtained ages around $125 \mathrm{ka}$ corresponding to OIS 5e. As the terraces occur at elevations between 2 and $4 \mathrm{~m}$ asl he suggested that the island was tectonically stable since the Late Pleistocene.

Meco et al. $(1992,1997)$ used the results of two U-series measurements at the site of Matas Blancas, palaeontological and altimetric data to conclude that there was a single positive oscillation of sea level during OIS 5e. In contrast, Zazo et al. (1997) used morphostratigraphic and geomorphological analyses together with a few U-series measurements and radiocarbon dating to propose changes of sea level during OIS 5e, and climate variability during OIS 1 in Fuerteventura and Lanzarote islands.

\subsection{El Berrugo (Lanzarote)}

The site is located at the southern tip of Lanzarote Island (Fig. 16), with a substratum of Miocene volcanic rocks. Low tide exposes a sequence of marine and terrestrial units (Fig. 17) briefly described here in ascending stratigraphic order.

Unit 1 is a well-cemented conglomerate with angular and rounded volcanic clasts in a red sandy-mudstone matrix. As the fossil content includes marine (mainly Patella sp.) and terrestrial (gastropod) shells, we consider that deposition took place in a transitional setting at the mouth of a creek.

Unit 2 rests upon the former deposits and is 


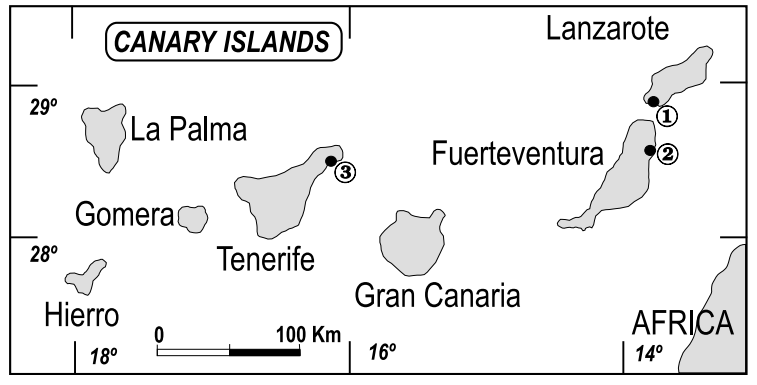

Fig. 16. Localities studied in Canary Islands. (1) El Berrugo; (2) Rosa J. Sánchez; (3) Igueste de San Andrés.

separated by a gentle erosional surface. It consists of well-cemented yellow calcarenite with interbedded conglomerate layers containing Strombus bubonius, Columbella rustica, Cerithium vulgatum, and Patella sp. The dip of bedding suggests some tilting towards land $(\mathrm{N})$.

Unit 3 is delineated by a sharp erosional surface, and consists of cemented conglomerate with volcanic and calcarenite pebbles eroded from the earlier described deposits, and marine fossils (Strombus bubonius, Conus sp., Patella sp.). It is interpreted as a prograding coarse-grained beach deposit with a well-preserved foreshore and berm facies.

The youngest unit preserved is a conglomerate with volcanic clasts overlying an erosional surface cut into deposits of unit 2, and is here assigned a Holocene age based on faunal content and geological correlation with sections nearby.

Four U-series measurements from units 1, 2, and 3 (Table 1) indicate a last-interglacial age but stratigraphic data, faunal content, and corre- lation with similar deposits in Lanzarote Island suggest deposition during OIS 5e in particular. The prominent erosional surface separating units 2 and 3 that involved incorporation of cemented rocks into the younger unit 3 suggests that sediments in unit 2 were cemented and exposed subaerially before deposition of unit 3 . This may be an indication for two highstands in this site.

\subsection{Rosa J. Sánchez}

Low tide exposes a sequence of alternating marine and terrestrial deposits $1 \mathrm{~km}$ to the north of Puerto del Rosario in Fuerteventura Island (Fig. 18). Terrestrial deposits are alluvial reddish sandy silts with scattered poorly rounded pebbles. All marine units (1 to 4) record very shallow waters and bear a rich fauna of Patella sp. and Thais haemastoma.

Unit 1 is fine-grained calcarenite. It underwent early cementation and is cut by joints filled with conglomerate derived from the erosion of younger marine units ( 2 to 4 ). The top of unit 1 is a prominent erosional surface, followed upwards by alluvial-fan deposits including channel-fill facies. The results of seven U-series measurements carried out on mollusc shells (Table 1) indicate a last-interglacial age for all marine units. The fossil content does not include representatives of the 'Senegalese' fauna, but Zazo et al. (1997) found Strombus bubonius in deposits laterally equivalent at Puerto del Rosario. Stratigraphic and sedimentological data suggest several oscillations of sea level during OIS $5 \mathrm{e}$. The one between units 1 and 2 seems to be the most pronounced.

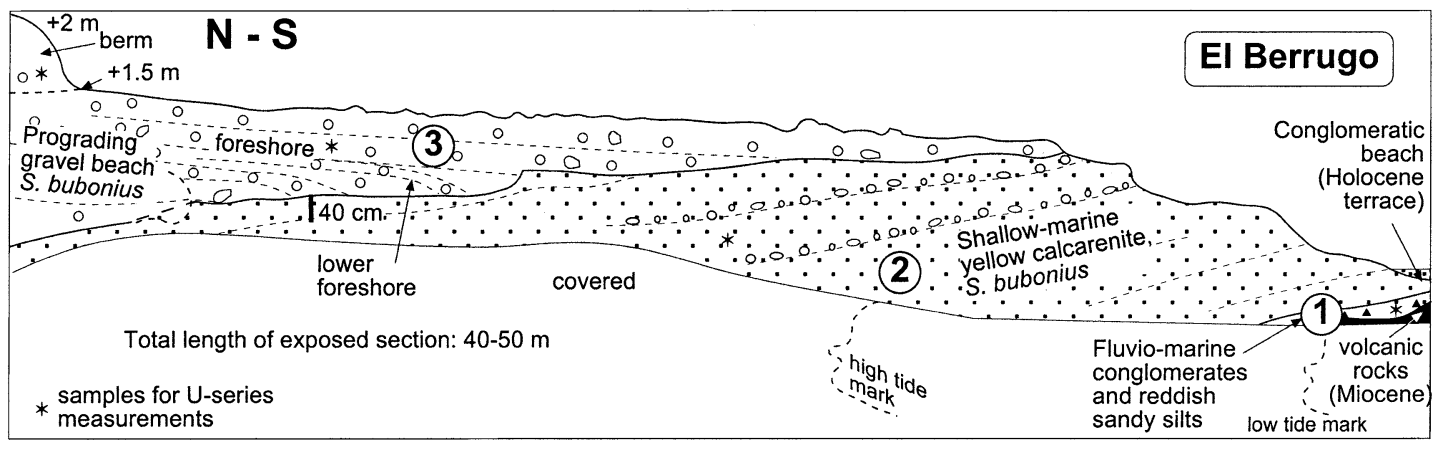

Fig. 17. Marine units in El Berrugo (Lanzarote). 


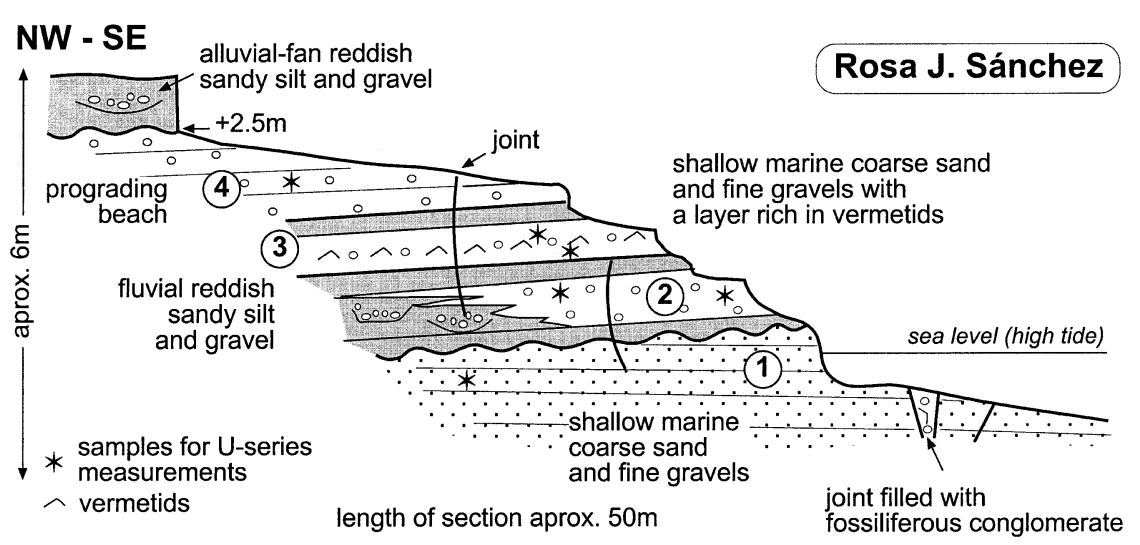

Fig. 18. Marine and terrestrial units in Rosa J. Sánchez (Fuerteventura).

\subsection{Playa de Igueste}

This is the first report of Pleistocene marine deposits bearing a warm-water fauna for Tenerife Island. Two superposed marine units can be observed in Igueste beach at low tide (Fig. 19). The oldest unit exposed contains reddish colluvial sandy silts with angular clasts of volcanic rocks. Above an erosional surface, marine unit 1 is represented by a conglomerate of volcanic pebbles with abundant red algae and fragments of the coral Siderastrea radians and a few Strombus bubonius deposited as a prograding beach with well preserved foreshore facies.

A terrestrial silty deposit (aeolian dune?, colluvium?) rich in gastropods (Helix sp.) overlies marine unit 1 (Fig. 19). The topmost unit 2 in Igueste comprises well-cemented beach conglomerates bearing Strombus bubonius, Patella candei, and Patella lowei.

\subsection{Geochronological interpretation}

U-series measurements on fossils from unit 2 gave an age of $131 \pm 1.60 \mathrm{ka}$ (Table 1$)$. Considering the faunal content and the stratigraphic architecture, it seems likely that the two units represent two highstands in OIS 5e. The low elevation at which the described marine deposits occur in the study sites suggests a tendency to subsidence in the last $130 \mathrm{ka}$. The rate of uplift obtained with the criteria indicated in Section 2 is $-0.011 \mathrm{~mm} /$ yr.

\section{Discussion}

With careful mapping, facies identification and reliable U-series dating, we are able to correlate the marine episodes recorded at the various study sites (Table 2). Our results provide new regionalscale insight into the tempo of coastal tectonics, periods of relatively high sea level during the Middle and Late Pleistocene, and switches in marine conditions during that period.

\subsection{The last interglacial}

The 'Senegalese' fauna, particularly Strombus bubonius, occurs commonly in all study areas during OIS 5 (Table 2). The more complete, best preserved sequences suggest the existence of three highstands during OIS 5e. According to the results of $34 \mathrm{U}$-series measurements by TIMS carried out in Campo de Tiro (Mallorca Island), OIS 5e lasted from 135 to $117 \mathrm{ka}$ (Hillaire-Marcel et al., 1996). These three highstands occur as different morphostratigraphic units separated by intervening terrestrial deposits and/or conspicuous erosional surfaces. In the Canary Islands only two $5 \mathrm{e}$ highstands are usually preserved.

Those eustatic changes were coupled to significant climate changes that are indicated by switches from oolitic to non-oolitic units in some sequences (La Marina-El Pinet quarry and Cope Basin). Abrupt changes in the faunal assemblages marked by the disappearance of Strombus bubonius and a part of the 'Senegalese' fauna are 


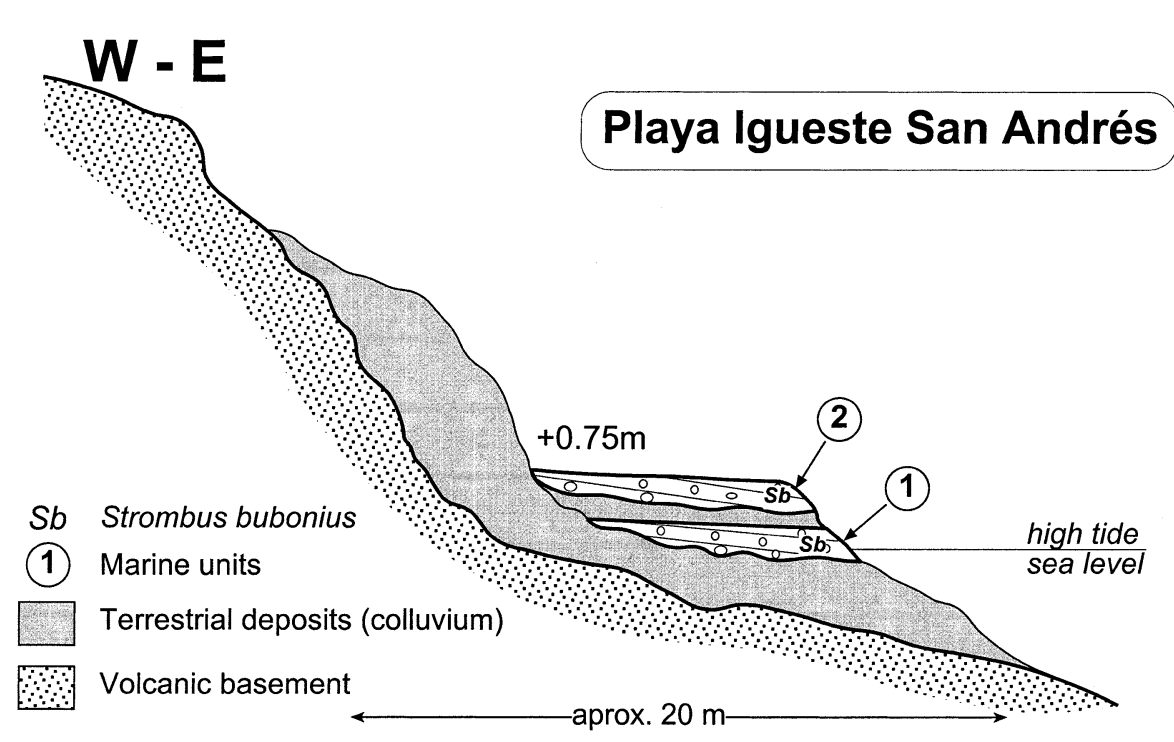

Fig. 19. Marine units and terrestrial deposits in Igueste de San Andrés (Tenerife).

Table 2

Tentative correlation of marine units (encircled figures) with indications of sedimentological and dynamic features, and faunal content in the studied sequences

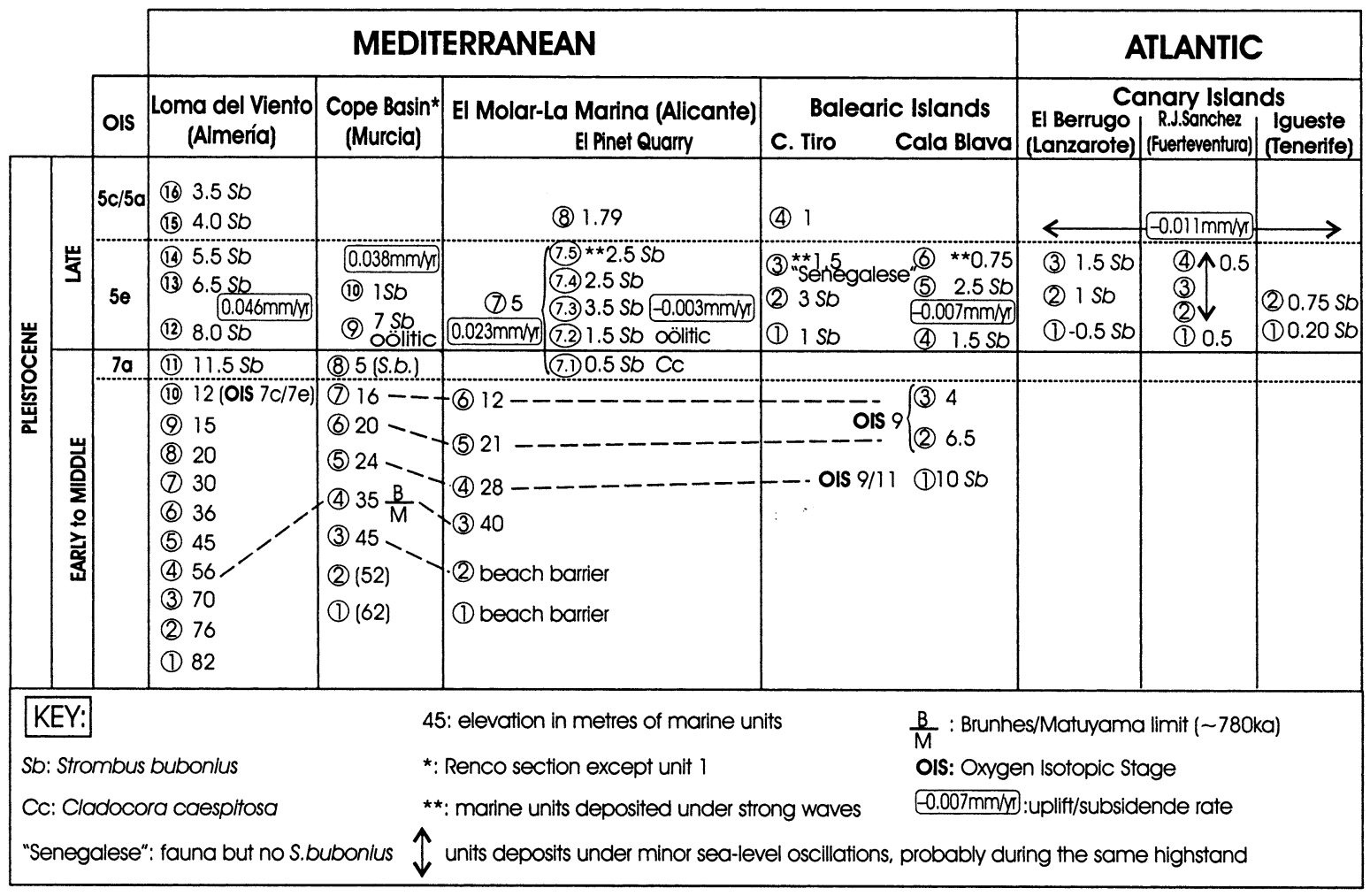


recorded at the end of OIS $5 \mathrm{e}$ in the Balearic islands. There is also a change in beach facies from sand and gravel to boulder accumulations in the same reddish mudstone matrix in the Balearic Islands and La Marina-El Pinet quarry. These features suggest more humid conditions and increased frequency of storms, along with a decrease of surface water temperature in some areas (Balearic Islands). This is a sharp contrast to the warmer, more arid conditions that reigned during the oldest highstand favouring the accumulation of oolitic facies and aeolian dunes.

In some areas there is record of one or two younger marine units (Table 2) that, according to U-series measurements, show the existence of at least one highstand with age post-OIS 5e and pre-Holocene. However, it is not clear whether it corresponds to OIS $5 \mathrm{c}$ or $5 \mathrm{a}$ given the scarce isotopic data.

\subsection{Penultimate interglacial}

In the littorals of Almería, Murcia and Alicante provinces there is record of at least one highstand marked by coastal deposits that always contain Strombus bubonius (although in numbers smaller than in units dated as OIS 5e). U-series measurements on Cladocora caespitosa found in unit 1, which also bears Strombus bubonius, at La Marina-El Pinet (Table 1), confirm the presence of the 'Senegalese' fauna in the Spanish coasts as early as OIS 7, probably OIS 7a as suggested by Goy et al. (1986b) and Hillaire-Marcel et al. (1986).

The occurrence of two offlapping units in Almería (10 and 11, Fig. 4) littoral may indicate two separate highstands during the penultimate interglacial, OIS 7e/7c and OIS 7a bearing Strombus bubonius.

\subsection{The older interglacials}

Correlation of marine units in the various study areas is most difficult owing to the variability of the preserved records. However, palaeomagnetic data from the Cope Basin suggest that the Matuyama-Brunhes reversal (780 ka) took place during deposition of unit 4 , meaning that unit 4 formed at least partially during the highstand correlative with OIS 19.

'Senegalese' fauna including Strombus bubonius occurs in unit 1 of Cala Blava, Balearic Islands (Table 2). Here, a transect normal to the coastline shows two more terraces (marine units 2 and 3, Fig. 15) between unit 1 and the marine units representing OIS 5e (units 4 to 6 in Fig. 15). Hearty (1987, fig. 7) used AAR to date the marine unit at Cape Orenol (directly correlatable with our unit 1) as $>300 \mathrm{ka}$ and included it in his 'aminozone' G (OIS 9). However, Hearty (1987) points out that the differentiation between 'aminozones' $F$ and $\mathrm{G}$ (representing OIS 7 and 9 in the Mediterranean realm) is poorly solved in the Balearic Islands. U-series measurements on mollusc shells collected from marine unit $2(6.5 \mathrm{~m}$ asl) indicate ages $>200 \mathrm{ka}$ (Stearns and Thurber, 1965). This suggests that unit 1 should correspond to OIS 9 or 11 .

Correlation of Cala Blava with the peninsular Loma del Viento, Cope Basin and La Marina-El Molar sites appears most questionable. The only consistent key points available are the palaeomagnetic results at Cope Basin and a change in the tectonic regime recorded in many places of the Betics at the beginning of the Middle Pleistocene (Goy et al., 1989), from subsidence to uplift in El Molar (Alicante) and different uplift rates in Almería and Murcia. Using these criteria a tentative correlation can be made connecting units 5, 6, and 7 in Cope with 4, 5, and 6 in El Molar-La Marina, and 1, 2, and 3 in Cala Blava (Table 2). Any attempt to extend these preliminary correlations to Loma del Viento (Almería) is not possible at the present stage.

\subsection{Palaeo-sea levels and tectonic implications}

Reconstructions of palaeo-sea levels based on marine units in tectonically active areas require cautions. The task is still more difficult when the ages involved exceed the range of application of the dating methods. Our calculations assume a palaeo-sea level $2 \mathrm{~m}$ asl during OIS $5 \mathrm{e}$ and a constant trend of local vertical movements (either uplift or subsidence) in the last $130 \mathrm{kyr}$ (see Section 2 ). Of course this is a simplistic view, but still it 
allows us to conclude that the number of marine units is larger in areas with high uplift rates $(0.046$ $\mathrm{mm} / \mathrm{yr}$ at Loma del Viento, Almería province, Table 2). Marine units in these areas probably record diverse Pleistocene highstands, but this requires discriminating terraces formed after sharp tectonic movements. While we consider that at least six marine terraces (16 through 11) generated in the last ca. $180 \mathrm{kyr}$, there are another 10 units (terraces 10 through 1) generated in the Early and most of the Middle Pleistocene.

The most reliable data indicate the widespread occurrence of three highstands during OIS 5e $(135-117 \mathrm{ka})$ found in all study areas (except at Cope Basin) under rates of vertical movement between +0.046 and $-0.007 \mathrm{~mm} / \mathrm{yr}$. There are references to the occurrence of more than one highstand in other areas: three highstands in Bahamas (Neumann and Hearty, 1996), two highstands in South Australia (Murray-Wallace et al., 1998), two highstands in the northern Red Sea and Gulf of Suez (Plaziat et al., 1998), and also two highstands in Sardinia Island in the western Mediterranean Sea (Kindler et al, 1997).

Most authors consider that sea level did not reach the present elevation during the highstands corresponding to OIS $5 \mathrm{c}$ and $5 \mathrm{a}$, but the proposed figures of palaeo-elevations vary greatly. Studies in Huon Peninsula, New Guinea, led Chappell et al. (1996) and Pillans et al. (1998) to suggest an average eustatic sea level $19 \mathrm{~m}$ bsl at $102 \mathrm{ka}$ (OIS 5c) and $87 \mathrm{ka}$ (OIS 5a). However, Roy and Boyd (1996) studied a tectonically stable area in south Australia and found that the palaeo-elevation of sea level during OIS 5c/5a was 3-5 m bsl. Data from the Bahamas (Hearty and Kauffman, 2000) suggest palaeo-positions around $18 \mathrm{~m}$ bsl during OIS $5 \mathrm{c}(\sim 100 \mathrm{ka})$ and close to present sea level for OIS $5 \mathrm{a}(\sim 80 \mathrm{ka})$.

The present study (Table 2) suggests the existence of at least one highstand after OIS 5e but pre-Holocene in Loma del Viento (unit 15, containing Strombus bubonius), in La Marina-El Pinet quarry (unit 8), and also Campo de Tiro, Balearic Islands (unit 4, containing 'Senegalese' fauna). The scarce U-series measurements (Hillaire-Marcel et al., 1986, 1996) give ages ca. 100 ka. This means deposition during a highstand with palaeo-sea level similar to the present, after discounting the post-sedimentary tectonic effects. There is still a younger, but pre-Holocene, marine unit (unit 16 with $S$. bubonius in Loma del Viento, see Table 2, and unit 9 in La Marina-El Pinet quarry, see Fig. 12) that can be related to OIS $5 \mathrm{c}$ or $5 \mathrm{a}$ given the scarce isotopic results. However, stratigraphic results suggest that, near the end of OIS 5, the sea level rose once or twice to positions close to the present values leaving behind highstand deposits observed in our coasts when subsidence rates are less than $0.003 \mathrm{~mm} / \mathrm{yr}$.

The occurrence of deposits during the penultimate interglacial (OIS 7) is evidenced by morphostratigraphic observations and U-series measurements on Cladocora caespitosa (unit 7.1, la Marina-El Pinet quarry, Table 1) and mollusc shells (unit 11, Loma del Viento, Hillaire-Marcel et al., 1986; Zazo and Goy, 1989) that yield ages around $180 \mathrm{ka}$ (OIS 7a). The present elevations of marine units (Table 2) and the faunal content (Strombus bubonius) indicate a highstand with palaeo-sea level slightly lower than during $5 \mathrm{e}$, but above or similar to present sea level. The marine unit corresponding to OIS $7 \mathrm{a}$ is observed only in areas with subsidence rates less than $0.003 \mathrm{~mm} / \mathrm{yr}$.

There are discrepancies concerning the position of sea level during OIS 7: Chappell and Shackleton (1986) deduced its elevation as $15 \mathrm{~m}$ bsl using sea level isotopic curves whereas Roy and Boyd (1996) stated it to be $2-4 \mathrm{~m}$ asl in the stable south Australia. Hearty and Kindler (1995) suggest palaeo-sea levels $2.5 \mathrm{~m}$ asl (OIS 7a) and $\leq 0 \mathrm{~m}$ (OIS 7c) in the Bahamas.

It is very risky to assign the older marine units found in the study area to any given interglacial with the present state of knowledge, but the available data in Cala Blava indicate that unit 1 can be related to OIS 9, or probably 11 , and unit 2 (and probably also unit 3) to OIS 9 (Table 2). The subsiding trend of the area does not permit deposits correlated to OIS 7 to outcrop above the present sea level.

The occurrence of a warm 'Senegalese' fauna in these units leads to three conclusions: (1) it is the oldest record of such fauna cited in the Western Mediterranean realm; (2) it confirms that the warm fauna entered the Mediterranean realm 
long before the last interglacial (OIS 5), as previously suggested by Hillaire-Marcel et al. (1986), Goy et al. (1986b), Zazo and Goy (1989); and (3) it proves that the superficial oceanic conditions during those highstands were analogous to those existing during OIS 5e.

Special attention has been paid in recent times to OIS 11 (420-360 ka), the longest and warmest interglacial event in the last $500 \mathrm{ka}$, as glossed by Droxler and Farrell (2000), however, there is no clear evidence of the degree of warming. The palaeo-position of sea level is also debated. Values of $17 \mathrm{~m}$ asl have been proposed by Murray-Wallace et al. (2001) in the stable South Australia, and by Hearty et al. (1999) in the Bahamas. The presence of a warmer fauna in deposits of OIS 11 was described in Chile in a dramatically exposed sequence of raised Pleistocene marine terraces (Ortlieb et al., 1996).

Results from the Vostok ice core (Petit et al., 1999) that records the last $420 \mathrm{ka}$ suggest that interglacials 5.5 and 9.3 are different from the Holocene, but similar to each other in duration (ca. $20 \mathrm{kyr}$ and $17 \mathrm{kyr}$ respectively), shape and amplitude. The data confirm that the warmest temperature at stage $7 \mathrm{e}$ was slightly warmer than the Holocene and with much shorter duration $(7 \mathrm{kyr})$ and show that stage 9.3 was at least as warm as stage 5.5. Data for stage 11.3 are more problematic as a consequence of the probability that the Vostok records are disturbed at the base of the core.

U-series from coral reefs on Henderson Island, in the extreme east of the Indo-Pacific Subtropical Province, suggested an exceptionally long and warm interglacial at $330 \mathrm{ka}$ corresponding to OIS 9.3 (Stirling et al., 2001).

Palaeomagnetic records of Cope Basin and tectonic data from El Molar-La Marina allow a tentative correlation between these areas and the Balearic Islands (Table 2), but it is much more problematic to do the same with Loma del Viento (Almería). The high number of marine units in Loma del Viento is not exceptional when compared with other areas where the geological setting is very precisely known and has been dated accurately. This is the case in South Australia where Huntley et al. (1993, 1994), Huntley and
Prescott (2001) and Murray-Wallace et al. (1996, 1998 , 2001) found 13 barriers younger than the Brunhes-Matuyama geomagnetic polarity reversal (780 ka).

\section{Conclusions}

The sequence of marine units analysed in this paper includes the sections located on the Mediterranean side of the Iberian Peninsula (Almería, Murcia, and Alicante), the Balearic Islands (Mallorca), and the Atlantic Canary Islands (Lanzarote, Fuerteventura, and Tenerife islands).

Sixteen marine units (terraces) within a set of 27 marine terraces occur at Loma del Viento (Almería) following tectonic activity of the Loma del Viento fault. Morphostratigraphic and neotectonic analyses allow us to disregard some terraces as having a non-eustatic origin. Sequences in Cope Basin (Murcia province) and El Molar-La Marina (Alicante province) include a smaller number of marine units. All these three areas have experienced uplift during the Pleistocene, with uplift rates between $0.046 \mathrm{~mm} / \mathrm{yr}$ (Loma del Viento) and $0.023 \mathrm{~mm} / \mathrm{yr}$ (El Molar-La Marina). In contrast, the other studied areas behaved as gently subsiding, with rates of vertical movements between $-0.003 \mathrm{~mm} / \mathrm{yr}$ (La Marina-El Pinet quarry, Alicante) and $-0.011 \mathrm{~mm} / \mathrm{yr}$ (Canary Islands). The calculations of rates of vertical movement assume that palaeo-elevation of sea level during OIS $5 \mathrm{e}$ was $2 \mathrm{~m}$ asl and that movement was constant and of the same sign (uplift/subsidence) for the last $130 \mathrm{kyr}$.

Correlation of the older marine units with OIS of Lower and Middle Pleistocene poses many problems. However, we have recognised units that correlate well with OIS $5 \mathrm{a} / 5 \mathrm{c}, 5 \mathrm{e}, 7,9$, and probably 11 . These units indicate sea levels equal to or higher than present.

Evidence for three highstands is recorded in most of the studied sites during OIS 5e (135-117 ka). The marine units deposited during these highstands contain abundant warm 'Senegalese' fauna. In some places oolitic sedimentation took place during the oldest highstand. We have used the presence or absence of these facies, Strombus 
bubonius and evidence of a period of increased wave action during the youngest highstand as criteria that indicate climatic and eustatic instability during OIS 5e. The occurrence of $S$. bubonius in sediments dated as OIS $7 \mathrm{a}$ at ca. $180 \mathrm{ka}$ (U-series measurements on mollusc shells and coral) in Almería and Alicante and an older OIS (9 or 11) demonstrates that the warm 'Senegalese fauna', assumed to derive from Equatorial Africa, entered the Mediterranean much before the last interglacial. The presence of such fauna during two Middle Pleistocene interglacials suggests that, assuming a constant salinity, sea-surface temperature in the Western Mediterranean did not change appreciably during these highstands.

Climate turned more humid by the end of OIS $5 \mathrm{e}$, as suggested by a change from oolitic to siliciclastic facies rich in red mudstone matrix, presumably generated by erosion of older red soils. Increased frequency of storms can be deduced from deposition of boulder beaches in Alicante and in the Balearic Islands at that time.

\section{Acknowledgements}

The authors are indebted to J. Cuerda who, besides working with them in the sites of Balearic Islands and classifying the faunas, offered open and scientific opinions. Drs B. Brooke, C. Murray-Wallace and an anonymous referee carefully reviewed the manuscript and provided plenty of good suggestions and improvements. Financial support came from the Spanish Dirección General de Enseñanza Superior (DGES) Projects PB980265 and PB98-0514. This paper is a contribution to IGCP Project 437 (Coastal environmental changes during sea-level highstands: A global synthesis with implications for management of future coastal change) and INQUA Sea Level Changes Commission and Neotectonics Commission.

\section{References}

Bardají, T., Civis, J., Dabrio, C.J., Goy, J.L., Somoza, L., Zazo, C., 1986. Geomorfología y Estratigrafía de las secuencias marinas y continentales cuaternarias de la Cuenca de
Cope (Murcia, España). In: López-Bermúdez, F., Thornes, J.B. (Eds.), Estudios sobre Geomorfología del Sur de España. University of Murcia, Murcia, pp. 11-16.

Bardají, T., Goy, J.L., Mörner, N.A., Zazo, C., Silva, P.G., Somoza, L., Dabrio, C.J., Baena, J., 1995. Towards a PlioPleistocene chronostratigraphy in Eastern Betic Basins (SE Spain). Geodin. Acta 8, 112-126.

Bardají, M.T., Silva, P.G., Goy, J.L., Zazo, C., Dabrio, C.J., Civis, J., 1999. Recent evolution of the Águilas Arc Basins (SE Spain): Sea-level record and neotectonics. INQUA Mediterr. Black Sea Shorelines Subc. Newsl. 21, 21-26.

Benedicto, A., Ramos, E., Casas, A., Sabat, E., Barón, A., 1993. Evolución tectonosedimentaria de la cubeta neógena de Inca (Mallorca). Rev. Soc. Geol. Esp. 6, 167-176.

Bernat, M., Busquet, J.C., Dars, R., 1978. $\mathrm{I}_{\mathrm{o}}-\mathrm{U}$ dating of the Oulgian stage from Torre García (southern Spain). Nature 275, 302-303.

Bernat, M., Echailler, J.V., Busquet, J.C., 1982. Novelles datations $\mathrm{I}_{\mathrm{O}}-\mathrm{U}$ sur des Strombes du Dernier Interglaciaire en Méditerranée. C.R. Acad. Sci. Paris II 295, 1023-1026.

Butzer, K.W., 1975. Pleistocene littoral-sedimentary cycles of the Mediterranean basin: A Mallorcan view. In: Butzer, K.W., Isaac, G. (Eds.), After the Australopithecines. Mouton Press, The Hague, 511 pp.

Butzer, K.W., Cuerda, J., 1962. Coastal stratigraphy of southern Mallorca and its implications for the Pleistocene chronology of the Mediterranean Sea. J. Geol. 70, 398-416.

Carracedo, J.C., Day, S., Guillou, H., Rodríguez-Badiola, E., Canas, J.A., Pérez-Torrado, J.F., 1998. Hotspot volcanism close to a passive continental margin: the Canary Islands. Geol. Mag. 135, 591-604.

Causse, Ch., Goy, J.L., Zazo, C., Hillaire-Marcel, C., 1993. Potentiel chronologique $(\mathrm{Th} / \mathrm{U})$ des faunes Pléistocènes méditerranéennes: exemple des terrasses marines des régions de Murcie et Alicante (Sud-est de l'Espagne). Geodin. Acta 6, 121-134.

Chappell, J., Shackleton, N.J., 1986. Oxygen isotopes and sea level. Nature 324, 137-140.

Chappell, J., Omura, A., Esat, T., Mcullogh, M., Pandolfi, J., Ota, Y., Pillans, B., 1996. Reconciliation of late Quaternary sea levels derived from coral terraces at Huon Peninsula with deep sea oxygen isotope records. Earth Planet. Sci. Lett. 141, 227-236.

Coppier, G., Griveaud, P., Larouziere, F.D., Montenat, Ch., Ott d'Estevou, Ph., 1989. Example of Neogene tectonic indentation in the Eastern Betic Cordilleras: the Arc of Aguilas (Southeastern Spain). Geodin. Acta 3, 37-51.

Cuerda, J., 1989. Los tiempos cuaternarios de las Baleares. Dir. Gral. Cultura, Conselleria de Cultura, Educació i Esports, Govern Balear, Mallorca, 305 pp.

Cuerda, J., Sacarés, J., 1992. El Quaternari al Migjorn de Mallorca. Dir. Gral. Cultura, Conselleria de Cultura, Educació i Esports, Govern Balear. Mallorca, 130 pp.

Dabrio, C.J., Goy, J.L., Zazo, C., 1985. A model of conglomeratic beaches in tectonically active areas (Late Pleistoceneactual, Almería, Spain). In: Rosell, J., Remacha, F., Zamorano, M. (Eds.), Proceedings 6th IAS European Congress. 
Inst. d'Estudis Illerdencs and Universitat Autónoma de Barcelona, Lleida, pp. 104-107.

Dabrio, C.J., Zazo, C., Goy, J.L., Santiesteban, C., Bardají, T., Somoza, L., Baena, J., Silva, P.G., 1991. Neogene and Quaternary fan-delta deposits in southeastern Spain. Cuad. Geol. Ibér. 15, 327-400.

Del Olmo, P., Alvaro, M., 1984. Control estructural de la sedimentación Neógena y Cuaternaria de Mallorca. I Congreso Español de Geología, Segovia, vol. 3, pp. 219-228.

Díaz del Rio, V., Somoza, L., Goy, J.L., Zazo, C., Rey, J., Hernández-Molina, J., Mateu, G., 1993. Mapa Fisiográfico de la Bahía de Palma. Publ. Espec. Inst. Esp. Oceanogr. Madrid 16, 39 pp.

Driscoll, E.M., Hendry, G.L., Tinkler, K.J., 1965. The geology and geomorphology of Los Ajaches, Lanzarote. Geol. J. 4, 321-334.

Droxler, A.W., Farrell, J.W., 2000. Marine Isotope Stage 11 (MIS 11): new insights for a warm future. Global Planet. Change 24, 1-5.

Fontes, J.C., Gasse, F., Gibert, E., 1996. Holocene environmental changes in Lake Bangong Basin (western Tibet); Part 1, Chronology and stable isotopes of carbonates of a Holocene lacustrine core. Palaeogeogr. Palaeoclimat. Palaeoecol. 120, 25-47.

Fornós, J.J., Barón, A., Pons, G.X., 1996. Arrecifes de coral hermatípicos (Cladocora caespitosa) en el relleno holoceno de la zona de Es Grau (Menorca, Mediterráneo Occidental). Geogaceta 20, 303-306.

Gignoux, M., 1913. Les formations marines pliocenes et quaternaires de l'Italie du sud et de la Sicilie. Ann. Univ. Lyon Ser. 36, 693 pp.

Goy, J.L., Zazo, C., 1982. Niveles marinos cuaternarios y su relación con la tectónica en el litoral de Almería (España). Bol. R. Soc. Esp. Hist. Nat. (Geol.) 80, 171-184.

Goy, J.L., Zazo, C., 1988. Sequences of the Quaternary marine levels in Elche Basin (Eastern Betic Cordillera, Spain). Palaeogeogr. Palaeoclimatol. Palaeoecol. 68, 301-310.

Goy, J.L., Zazo, C., 1989. The role of neotectonics in the morphologic distribution of the Quaternary marine and continental deposits of the Elche Basin, southeast Spain. Tectonophysics 163, 219-225.

Goy, J.L., Zazo, C., Dabrio, C.J., Hillarie-Marcel, C., 1986a. Evolution des systèmes lagons-îles Barrière du Tyrrhénien a l'actualité à Campo de Dalías (Almería, Espagne). Edit. Orstom. Coll. Trav. Doc. Paris 137, 169-171.

Goy, J.L., Zazo, C., Hillaire-Marcel, C., Causse, C., 1986 b. Stratigraphie et chronologie (U/Th) du Tyrrhénien de SE de l'Espagne. Z. Geomorphol. 62, 71-82.

Goy, J.L., Zazo, C., Somoza, L., Dabrio, C.J., Bardají, T., 1989. Litoral Béticas Orientales. In: Zazo, C., Dabrio, C.J., Goy, J.L. (Eds.), Libro Guía Excursión B, 1: Litoral Mediterráneo, II Reunión Cuaternario Ibérico, Madrid, 99 pp.

Goy, J.L., Hillaire-Marcel, C., Zazo, C., Cuerda, J., 1993 a. The Last Interglacial in the Baleares Islands: Morphosedimentary record and neotectonic implications. INQUA Mediterr. Black Sea Shorelines Subc. Newsl. 15, 23-25.
Goy, J.L., Zazo, C., Bardají, T., Somoza, L., Causse, C., Hillaire-Marcel, C., 1993b. Eléments d'une chronostratigraphie du Tyrrhénien des régions d'Alicante-Murcia, Sud-est de l'Espagne. Geodin. Acta 6, 103-119.

Goy, J., Zazo, C., Dabrio, C.J., Lario, J., Borja, F., Sierro, F.J., Flores, J.A., 1996. Global and regional factors controlling changes of coastlines in southern Iberia (Spain) during the Holocene. Quat. Sci. Rev. 15, 773-780.

Goy, J.L., Zazo, C., Cuerda, J., 1997. Evolución de las áreas margino-litorales de la Costa de Mallorca (I. Baleares) durante el Último y Presente Interglacial Nivel del mar Holoceno y clima. Bol. Geol. Min. 108, 127-135.

Hearty, P.J., 1986. An inventory of the last interglacial (s.1.) age deposits from the Mediterranean basin: a study of isoleucine epimerisation and U-series dating. Z. Geomorphol. Suppl.-Bd. 62, 51-69.

Hearty, P.J., 1987. New data on the Pleistocene of Mallorca. Quat. Sci. Rev. 6, 245-257.

Hearty, P.J., Kindler, P., 1995. Sea-level high-stand chronology from stable carbonate platforms (Bermuda and the Bahamas). J. Coast. Res. 11, 675-689.

Hearty, P.J., Kauffman, D.S., 2000. Whole-rock aminostratigraphy and Quaternary sea-level history of the Bahamas. Quat. Res. 54, 163-173.

Hearty, P.J., Miller, G.H., Stearns, Ch.E., Szabo, B.J., 1986. Aminostratigraphy of Quaternary shorelines in the Mediterranean basin. Geol. Soc. Am. Bull. 97, 850-858.

Hearty, P.J., Hollin, J.T., Dumas, B., 1987. Geochronology of Pleistocene littoral deposits on the Alicante and Almería coasts of Spain. Trab. Neóg.-Cuat. 10, 95-107.

Hearty, P.J., Kindler, P., Cheng, H., Edwards, R.L., 1999. A $+20 \mathrm{~m}$ middle Pleistocene sea-level highstand (Bermuda and the Bahamas) due to partial collapse of Antartic ice. Geology $27,375-378$.

Hernández-Pacheco, F., 1969. Los niveles de playas cuaternarias de Lanzarote. Rev. R. Acad. C. Exactas Fís. Nat. Madrid 63, 903-961.

Hillaire-Marcel, C., Carro, O., Causse, C., Goy, J.L., Zazo, C., 1986. Th/U dating of Strombus bubonius bearing marine terraces in southeastern Spain. Geology 14, 613-616.

Hillaire-Marcel, C., Gariepy, C., Ghaleb, B., Goy, J.L., Zazo, C., Cuerda, J., 1996. U-series measurements in Tyrrhenian deposits from Mallorca. Further evidence for two last interglacials high sea-levels in the Balearic Islands. Quat. Sci. Rev. 15, 53-62.

Huntley, D.J., Hutton, J.T., Prescott, J.R., 1993. The stranded beach-dune sequence of south-east South Australia: a test of thermoluminescence dating, 0-800 ka. Quat. Sci. Rev. 12, 120.

Huntley, D.J., Hutton, J.T., Prescott, J.R., 1994. Further thermoluminescence dates from the dune sequence in the southeast of South Australia. Quat. Sci. Rev. 13, 201-207.

Huntley, D.J., Prescott, J.R., 2001. Improved methodology and the new thermoluminescence ages for the dune sequence in south-east South Australia. Quat. Sci. Rev. 20, 687-699.

Issel, A., 1914. Lembi fossiliferi quaternari e recenti nella Sardegna meridionale. R.C. Acad. Linei 5, 759-770. 
Kaufman, A., Broecker, W.S., Ku, T.L., Thurber, D.L., 1971. The status of U-series methods of mollusk dating. Geochim. Cosmochim. Acta 35, 1155-1183.

Kaufman, A., Ghaleb, B., Wehmiller, J.F., Hillaire-Marcel, C., 1996. Uranium concentration and isotope ratio profiles within Mercenaria shells: Geochronological implications. Geochim. Cosmochim. Acta 60, 3735-3746.

Kindler, P., Davaud, E., Strasser, A., 1997. Tyrrhenian coastal deposits from Sardinia (Italy): a petrographic record of high sea levels and shifting climate belts during the last interglacial (isotopic substage 5e). Pelaeogeogr. Palaeoclimatol. Palaeoecol. 133, 1-25.

Labonne, M., Hillaire-Marcel, C., 2000. Geochemical gradients within modern and fossil shells of Concholepas concholepas from Northern Chile: An insight into U-Th systematics and diagenetic/authigenic isotopic imprints in mollusk shells. Geochim. Cosmochim. Acta 60, 1523-1534.

Lecointre, G., Tinkler, K.J., Richards, G., 1967. The marine Quaternary of the Canary Islands. Acad. Nat. Sci. Philadelphia Proc. 119, 325-344.

McLaren, S.J., Rowe, P.J., 1996. The reliability of uraniumseries mollusc dates from the western Mediterranean basin. Quat. Sci. Rev. 15, 709-717.

Meco, J., 1977. Los Strombus neógenos y cuaternarios del Atlántico euroafricano, taxonomía, bioestratigrafía y paleoecología. Ph.D. Thesis, Univ. Complutense de Madrid, Spain. Cabildo, Gran Canaria, 207 pp.

Meco, J., Petit-Maire, N., Reyss, J.L., 1992. Le courant dés Canaries pendant le stade isotopique 5 d'après la composition faunistique d'un haut niveau marin a Fuerteventura $\left(28^{\circ}\right.$ N). C.R. Acad. Sci. Paris Sér. II 314, 203-208.

Meco, J., Petit-Maire. N., Fontugne, M., Shimmield, G., Ramos, A.J., 1997. The Quaternary deposits in Lanzarote and Fueteventura (Eastern Canary Islands, Spain): An overview. In: Meco, J., Petit-Maire, N. (Eds.), Climates of the Past, Proceedings CLIP Project, 1995, pp. 123-136.

Montenat, C., 1973. Les formations néogènes et quaternaires du Levant espagnol. Thèse d'Etat, Univ. Paris-Orsay, 1170 pp.

Montenat, C., Reneville, P., Bizon, G., 1978. Le Néogène des environs d'Aguilas (Provinces de Murcia et d'Almería), Cordillères Bétiques, Espagne. B. Mus. Natl. Hist. Nat. Paris, 3, Sci. Terre 68, 37-54.

Montenat, C., Ott D’Estevou, P., Masse, P., 1987. Tectonicsedimentary characters of the Betic Neogene basins evolving in a crustal transcurrent shear zone (SE Spain). Bull. Cent. Rech. Elf E 11, 1-22.

Murray-Wallace, C., Belpeiro, A.P., 1991. The last interglacial shoreline in Australia - a review. Quat. Sci. Rev. 10, 441461.

Murray-Wallace, C.V., Cann, J.H., Huntley, D.A., Prescott, J.R., 1996. Late Quaternary uplift history, Mount Gambier region, South Australia. Z. Geomorphol. 106, 41-56.

Murray-Wallace, C.V., Belperio, A.P., Cann, J.H., 1998. Quaternary neotectonism and intra-plate volcanism: the Coorong to Mount Gambier Coastal Plain, southeastern Australia: a review. In: Stewart, I.S., Vita-Finzi, C. (Eds.),
Coastal Tectonics. Geol. Soc. London. Spec. Publ. 146, 255-267.

Murray-Wallace, C.V., Brooke, B.P., Cann, J.H., Belpeiro, A.P., Bourman, R.P., 2001. Whole-rock aminostratigraphy of the Coorong Coastal Plain, South Australia: towards a one million year record of sea-level highstands. J. Geol. Soc. London 158, 111-124.

Neumann, A.C., Hearty, P.J., 1996. Rapid sea-level at the close of the last Interglacial (Substage 5e) recorded in Bahamian Island geology. Geology 24, 775-778.

Ortlieb, L., Ghaleb, B., Hillaire-Marcel, C., Machare, J., Pichet, P., 1992. Déséquilibres U/Th, rapports D-alloisoleucine/L-isoleucine et teneurs en ${ }^{18} \mathrm{O}$ des mollusques de dépôts littoraux pléistocènes du sud du Pérou; une base d'appréciation chronostratigraphique. C.R. Acad. Sci. Paris II 314, 101-107.

Ortlieb, L., Hillaire-Marcel, C., Ghaleb, B., Goy, J.L., Zazo, C., Díaz, A., Guzmán, N., 1996. Was Isotopic stage 11 the warmest Interglacial Episode? Eastern Pacific Marine Terrace data. 5th Annual CLIP Meeting, Punta Cardon, Paraguaná, state of Flacon, Abstracts Volume, pp. 22 23.

Petit, J.R., Jouzel, J., Raynaud, D., Barkov, N.I., Barnola, J.M., Basile, I., Benders, M., Chappellaz, J., Davis, M., Delaygue, G., Delmotte, M., Kotlyakov, V.M., Legrand, M., Lipenkov, V.Y., Lorius, C., Pépin, L., Rithz, C., Saltzman, E., Stievenard, M., 1999. Climate and atmospheric history of the past 420,000 years from the Vostok ice core, Antartica. Nature 399, 429-436.

Pillans, B., Chapell, J., Naish, T.R., 1998. A review of the Milankovitch climatic beat: template for Plio-Pleistocene sea-level changes and sequence stratigraphy. Sediment. Geol. 122, 5-21.

Plaziat, J.C., Reyss, J.L., Choukri, A., Orszag-Sperber, F., Baltzer, F., Purser, H., 1998. Mise en évidence, sur la côte récifale d'Egypte, d'une regresión interrompant birèvement le plus haut niveau du Dernier Interglaciaire (5e): un nouvel indice de variations glacio-eustatiques à haute fréquence au Pléistocene? Bull. Soc. Géol. Fr. 169, 115-125.

Radtke, U., 1985. Untersuchungen zur zeitlichen Stellung mariner Terrasen und Kalkrusten auf Fuerteventura (Kanarische Inseln, Spanien). Kieler Geogr. Schr. 62, 73-95.

Rose, J., Meng, X., Watson, C., 1999. Palaeoclimatic and palaeoenvironmental responses in the western Mediterranean over the last $140 \mathrm{ka}$ : evidence from Mallorca, Spain. J. Geol. Soc. London 156, 435-448.

Roy, P.S., Boyd, R., 1996. Quaternary Geology of a tectonically stable, wave dominated, sediment-deficient margin, Southeast Australia. IGCP Project 367, Field Guide to the Central South Wales Coast. New South Wales Geological Survey, Sydney, 174 pp.

Shackleton, N.J., Opdyke, N.D., 1973. Oxygen isotope and paleomagnetic stratigraphy of equatorial Pacific core V28238: Oxygen isotope temperature and ice volumes on a $10^{5}$ year and $10^{6}$ year time scale. Quat. Res. 3, 39-55.

Shackleton, N.J., Opdyke, N.D., 1976. Oxygen isotope and paleomagnetic stratigraphy of Pacific core V28-239. Late 
Pliocene to latest Pleistocene. Geol. Soc. Am. Mem. 145, 449-464.

Silva, P.G., Goy, J.L., Somoza, L., Zazo, C., Bardají, T., 1993. Landscape response to strike-slip faulting linked to collisional settings: Quaternary tectonics and basin formation in the Eastern Betics, southeastern Spain. Tectonophysics 224, 289-303.

Somoza, L., 1993. Estudio del Cuaternario litoral entre Cabo de Palos y Guardamar (Murcia-Alicante). Las variaciones del nivel del mar en relación con el contexto geodinámico. Publ. Esp. Inst. Esp. Oceanogr. Madrid, 12, 237 pp.

Stearns, Ch., Thurber, D., 1965. ${ }^{230} \mathrm{Th} /{ }^{234} \mathrm{U}$ dates of late Pleistocene marine fossils from the Mediterranean and Moroccan littorals. Quaternaria 7, 29-41.

Stearns, Ch., Thurber, D., 1967. ${ }^{230} \mathrm{Th} /{ }^{234} \mathrm{U}$ dates of Pleistocene marine fossils from the Mediterranean and Moroccan littorals. Prog. Oceanogr. 4, 293-305.

Stirling, C.H., Esat, T.M., Lambeck, K., McCulloch, M.T., Blake, S.G., Lee, D.-C., Halliday, A.N., 2001. Orbital forcing of the Marine Isotope Stage 9 Interglacial. Science 291, 290-292.

Zazo, C., Goy, J.L., 1989. Sea level changes in the Iberian Peninsula during the last 200.000 years. In: Scott, D., Piraz- zoli, P., Honing, G. (Eds.), Late Quaternary correlations and applications. Kluwer Academic, Dordrecht, 256, pp. 27-39.

Zazo, C., Goy, J.L., Dabrio, C.J., Bardají, T., Somoza, L., Silva, P.G., 1993. The Last Interglacial in the Mediterranean as a model for the Present Interglacial. Global Planet. Change 7, 109-117.

Zazo, C., Hillaire-Marcel, C., Goy, J.L., Ghaleb, B., Hoyos, M., 1997. Cambios del nivel del mar-clima en los últimos 250 ka: Canarias orientales, España. Bol. Geol. Min. 108, 487-497.

Zazo, C., Bardají, T., Dabrio, C.J., Goy, J.L., Hillaire-Marcel, C., 1998. Record of Late Pliocene and Quaternary sea-level changes in coastal settings, southeast Spain. In: MeléndezHevia, A., Soria, A.R. (Eds.), 15th International Congress of Sedimentology, Alicante, Spain. ITGE, Madrid, pp. 159169.

Zazo, C., Silva, P.G., Goy, J.L., Hillaire-Marcel, C., Ghaleb, B., Lario, J., Bardají, T., González, A., 1999. Coastal uplift in continental collision plate boundaries: data from the Last Interglacial marine terraces of the Gibraltar Strait area (South Spain). Tectonophysics 301, 95-109. 